This document is confidential and is proprietary to the American Chemical Society and its authors. Do not copy or disclose without written permission. If you have received this item in error, notify the sender and delete all copies.

\title{
Multifunctional nanoparticles by coordinative self-assembly of His-tagged units with metal-organic frameworks
}

\begin{tabular}{|c|c|}
\hline Journal: & Journal of the American Chemical Society \\
\hline Manuscript ID & ja-2016-11934z.R1 \\
\hline Manuscript Type: & Article \\
\hline Date Submitted by the Author: & 07-Jan-2017 \\
\hline Complete List of Authors: & $\begin{array}{l}\text { Röder, Ruth; Ludwig-Maximilians-University Munich, Department of } \\
\text { Pharmacy } \\
\text { Preiß, Tobias; Ludwig-Maximilians-Universitat Munchen } \\
\text { Hirschle, Patrick; Ludwig-Maximilians-Universität München, Department of } \\
\text { Chemistry } \\
\text { Steinborn, Benjamin; Ludwig-Maximilians-Universitat Munchen, Pharmacy } \\
\text { Zimpel, Andreas; Ludwig-Maximilians-Universitat Munchen } \\
\text { Hoehn, Miriam; LMU, } \\
\text { Rädler, Joachim; Ludwig-Maximilians-University Munich Lehrstuhl für } \\
\text { Biophysik / soft condensed matter, CeNS \& Physik } \\
\text { Department,Geschwister-Scholl-Platz 1, D-80539 München, Germany } \\
\text { Bein, Thomas; Ludwig-Maximilians-Universität München, Chemistry and } \\
\text { Biochemistry } \\
\text { Wagner, Ernst; LMU Munich, Department of Pharmacy } \\
\text { Wuttke, Stefan; University of Munich, Chemisry } \\
\text { Lächelt, Ulrich; Ludwig-Maximilians-University Munich, Department of } \\
\text { Pharmacy }\end{array}$ \\
\hline
\end{tabular}




\section{INTRODUCTION}

Nanoparticles (NPs) that combine different functional domains are of high interest for various scientific disciplines requiring multifunctionality at the nanoscale. The controlled manipulation of the external surface of NPs is of paramount importance as it defines the interface between the NP and its surroundings and strongly determines the overall performance of the NP especially in biologic environments ${ }^{1,2}$. Researchers have shown that surface functionalization is a powerful tool for the creation of programmable NP interfaces. In this respect, the self-assembly of the functional units onto the NPs surface appears as a powerful approach because it would ensure a defined arrangement of these units without any guidance from an external source. Examples of self-assembly processes used for the generation of multifunctional colloidal NPs are micelle, liposome or polymerosome formation of amphiphilic compounds ${ }^{3-6}$ and cyclodextrin-adamantane host-guest interactions ${ }^{7,8}$. Especially for biomedical applications, multifunctional NPs that interact with biological systems at the molecular level and perform tasks within cellular systems are in great demand $d^{9,10}$. The intracellular delivery of biomacromolecules, such as peptides and proteins, represents a particularly challenging task. Several different barriers have to be overcome, including cellular uptake, endosomal escape, intracellular trafficking and cargo release $\mathrm{e}^{11,12}$. The heterogeneity of this compound class (hydrophilicity, charge, functional groups) hampers the development of universal delivery platforms. For this reason, nanocarriers with a functionalization mode, which is independent from the individual properties of the functional units, would be advantageous.

Here, we present the coordinative interaction of oligohistidine-tags with metal-organic frameworks (MOFs) as a novel external functionalization concept for MOF NPs based on a self-assembly process. MOFs are a class of materials synthesized of inorganic building units, metal ions or metal oxide clusters, which are coordinatively connected by organic linkers to create porous threedimensional frameworks (Figure 1a) ${ }^{13}$. Their crystallinity, chemically functionalizable pores and potential systematic structural variation are some factors amongst others that allow to precisely design these materials for particular purposes ${ }^{14,15}$. Regarding biomedical applications, the 
hybrid MOF nature provides the advantageous potential of degradability and disintegration into the low molecular weight components which can be eliminated from the body ${ }^{16-19}$. Different research groups have already reported pioneering examples of MOF NPs as transport vehicles for the delivery of biologically active molecules ${ }^{16,20-27}$. Here the combination of MOF high surface area for high drug loading and the possibility to engineer the internal surface to control MOF scaffold-guest interaction was used to optimize the nanocarrier performance ${ }^{28}$. Even, biomacromolecules such as proteins, DNA or enzymes could be recently encapsulated into MOFs ${ }^{29,30}$ or the MOF scaffold itself could be used as a part of the therapeutic principle $\mathrm{e}^{3-34}$. Therefore, combining the rich and versatile bulk chemistry of MOF materials with controlled and programmable NP interfaces may lead to novel multifunctional nanosystems ${ }^{35-40}$. Our concept uses the interaction between Lewis bases, such as the imidazole function of histidine and coordinatively unsaturated metal sites (CUS) present on the external surface of MOF NPs (Figure $1 \mathrm{~b}$ ) to self-assemble different functional units (Figure $1 c)$

a)

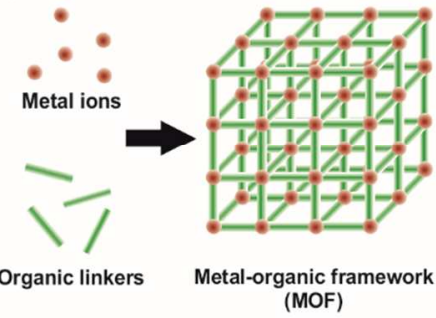

b)

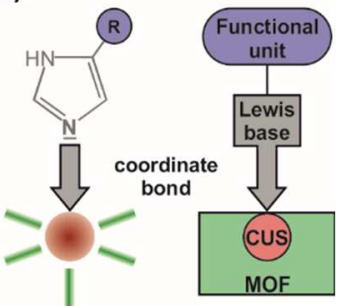

c)

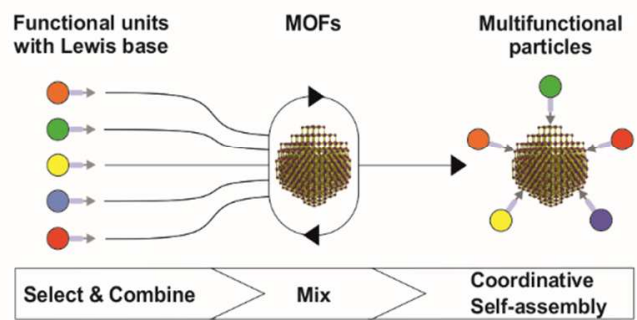

Figure 1. Illustration of coordinative self-assembly of Histagged molecules with MOF NPs: a) molecular composition of MOFs; b) coordinative bond between the imidazole group of histidines acting as Lewis base and coordinatively unsaturated metal sites (CUS) acting as Lewis acid; c) multifunctional MOF NPs generated by coordinative attachment of different functional units via self-assembly.

The exemplary set of (oligohistidine-tag) functional units used in this study is summarized in Table 1. Since His-tags can be readily integrated into peptides or proteins by synthetic, recombinant or bioconjugation techniques, they appear to be ideal connectors to create a versatile inorganic/bioorganic interface at the MOF NPs' surface. The same interaction (Figure $1 \mathrm{~b}$ ) is routinely used for the purification of recombinant proteins by immobilized metal ion chromatography ${ }^{41,42}$. Applicability of the coordinative His-tag interactions for intracellular delivery of proteins has been demonstrated before by using conjugates of nitrilo-triacetic acid derivatives and cellpenetrating peptides ${ }^{43,44}$, polymers ${ }^{45}$ or silica $\mathrm{NPs}^{46}$. In these approaches, the delivery platforms and vehicles were synthetically modified with separate metalchelators. Since the metal-sites already are an integral part of the coordinative MOF structure, the external secondary modification via coordinate bonds in the presented approach of 'self-assembling multifunctional coordination particles' (SAMCOPs) is considered a powerful tool for the combinatorial and stoichiometric generation of functional MOFs.

Table 1. His-tagged functional units used for the assembly with MOF NPs.

\begin{tabular}{|c|c|c|}
\hline Code & Sequence $^{[\mathrm{a}]} /$ Description & Function \\
\hline $\begin{array}{l}\mathrm{H}_{6}-\mathrm{Acr} \\
\mathrm{H}_{0 / 3 / 6}-\mathrm{Acr}\end{array}$ & $\begin{array}{l}\text { Acridine- } \mathrm{PEG}_{28}-\mathrm{H}_{6} \mathrm{NH}_{2} \\
\text { Acridine-STOTDA-H } \mathrm{H}_{0 / 3 / 6}\end{array}$ & $\begin{array}{l}\text { Photometric } \\
\text { detection }\end{array}$ \\
\hline $\mathrm{H}_{0 / 3 / 6}-\mathrm{FITC}$ & FITC-STOTDA-H 6 & \\
\hline $\mathrm{H}_{6}-\mathrm{A} 647 \mathrm{~N}$ & ATTO647N-PEG ${ }_{12}-\mathrm{H}_{6} \mathrm{NH}_{2}$ & $\begin{array}{l}\text { Fluorescence } \\
\text { detection }\end{array}$ \\
\hline $\mathrm{H}_{6}-\mathrm{CF}$ & Carboxyfluorescein-PEG ${ }_{12}-\mathrm{H}_{6} \mathrm{NH}_{2}$ & \\
\hline $\mathrm{H}_{6}$-GFP & Recombinant eGFP ( $\mathrm{H}_{6}$-Tag) & \\
\hline$H_{6}-T f^{*}$ & $\begin{array}{l}\text { Transferrin conjugated with } \mathrm{H}_{6}-\mathrm{PEG}_{36} \text { and } \\
\text { ATTO647N }\end{array}$ & $\begin{array}{l}\text { Model pro- } \\
\text { teins }\end{array}$ \\
\hline $\mathrm{H}_{6}$-Bak & $\mathrm{H}_{6}$-GGQVGRQLAIIGDDINRNH${ }_{2}$ & \\
\hline $\mathrm{H}_{6}-\mathrm{Bad}$ & $\mathrm{H}_{6}$-GNLWAAQRYGRELRRMSDEFVDNH $\mathrm{N}_{2}$ & $\begin{array}{l}\text { Apoptotic } \\
\text { peptides }\end{array}$ \\
\hline $\mathrm{H}_{6}-\mathrm{KLK}$ & $\mathrm{H}_{6}$-GGKLAKLAKKLAKLAKNH${ }_{2}$ & \\
\hline $\mathrm{H}_{6}$-CytC & Cytochrome $\mathrm{C}$ conjugated with $\mathrm{H}_{6}$ & $\begin{array}{l}\text { Apoptotic } \\
\text { protein }\end{array}$ \\
\hline
\end{tabular}

\section{RESULTS AND DISCUSSION}

Selection and characterization of MOF NPs. A set of three exemplary MOF structures, MIL-88A $\left(\mathrm{Fe}^{3+} /\right.$ fumaric acid $)^{16}$, HKUST-1 $\left(\mathrm{Cu}^{2+} / \text { trimesic acid }\right)^{47}$ and $\mathrm{Zr}$-fum $\left(\mathrm{Zr}^{4+} / \text { fumaric acid }\right)^{48,49}$ was selected for testing the assembly strategy. HKUST-1 was chosen based on the high Histag affinity toward chelated $\mathrm{Cu}^{2+}$, which even exceeds affinity toward $\mathrm{Ni}^{2+}$ and $\mathrm{Co}^{2+}{ }^{50,51}$. MIL-88A and $\mathrm{Zr}$-fum represent well established MOFs with potential for biomedical applications ${ }^{16,18}$. Although $\mathrm{Ni}^{2+}, \mathrm{Co}^{2+}$ and $\mathrm{Zn}^{2+}$ are known to have high affinity to His-tags ${ }^{50,51}$, we did not include them in the study due to the expected cytotoxicity of $\mathrm{Ni}^{2+}$ and $\mathrm{Co}^{2+}$ MOFs and the low stability of $\mathrm{Zn}$-based MOFs in aqueous media. Together, the set covers a range of well-established MOF species with individual material characteristics and each based on a different di-, tri- or tetravalent metal component with expected different Histag binding capacities.

The quality of the MOF NPs used in this study was ensured by applying multiple complementary characterization techniques: scanning electron microscopy (SEM, Figures S10-S15), dynamic light scattering (DLS, Figures 
S1-S2, Table S2), X-ray diffraction (XRD, Figures $\mathrm{S}_{3}-\mathrm{S}_{5}$ ), thermogravimetric analysis (TGA, Figures S6-S8) and nitrogen sorption measurements providing the surface area (Figure S9, Table S3). Powder XRD patterns were determined for all MOF NP species (Figures $\mathrm{S}_{3}-\mathrm{S}_{5}$ ). The diffractograms were used to verify the successful synthesis of the MOF species as well as to show the high crystallinity of the Zr-fum and HKUST-1 NPs. It should be noted that the poor crystallinity of the MIL-88A NPs are expected and have been frequently reported and discussed in the literature ${ }^{16,52-55}$. At the same time XRD was used to prove the stability of the three MOFs under the later used conditions (Figures $\mathrm{S}_{3}-\mathrm{S}_{5}$ ). For additional bulk characterization, all NP species were examined with both nitrogen sorption experiments (Figure S9, Table S3) and TGA (Figures S6-S8). The microporosity of all three NP species ranging from 0.6 up to $1.5 \mathrm{~nm}$ was confirmed and the BET surface area yielded typical results ${ }^{16,47-49}$. Thus, we have successfully synthesized the MIL-88A, HKUST-1 and Zrfum MOF structures with their expected bulk properties.

In order to characterize their corresponding NP properties a combination of two techniques were used: particle size distributions were determined via scanning electron microscopy (SEM, Figures S10-S15) for the dried species and, more importantly, for the dispersed species via dynamic light scattering (DLS, Figures S1-S2, Table S2). For $\mathrm{Zr}$-fum, SEM measurements resulted in a diameter of (84 $\pm 7) \mathrm{nm}$ for the dried particles. The corresponding $\mathrm{z}$ average diameter measured via DLS in water was determined at $(182 \pm 4) \mathrm{nm}$ with a polydispersity index (PDI) of 0.205 . This deviation towards larger diameters is to some extent expected, since DLS provides the hydrodynamic diameter of the particles and is influenced amongst others by particle-solvent interactions and aggregation ${ }^{5,57}$. The other MOFs behave similarly: DLS experiments resulted in an average intensity based diameter of $(191 \pm 1) \mathrm{nm}$ $(\mathrm{PDI}=0.130)$ for MIL-88A and $(530 \pm 27) \mathrm{nm}(\mathrm{PDI}=$ 0.290) for HKUST-1 with the corresponding dried particle size distributions of $(61 \pm 7) \mathrm{nm}$ for MIL-88A and for HKUST-1 (177 \pm 39$) \mathrm{nm}$. We suppose that the main reason for the larger NP diameters determined using DLS is due to the fact that the MOF samples reveal agglomeration behavior in solution ${ }^{56}$.

Photometrical analysis of His-tag binding to MOF NPs. The binding of different His-tag model peptides (e.g. $\mathrm{H}_{\mathrm{n}}$-Acr, $\mathrm{H}_{\mathrm{n}}$-FITC, $\left.\mathrm{H}_{6}-\mathrm{A} 647 \mathrm{~N}\right)$ to MIL-88A, HKUST-1 and $\mathrm{Zr}$-fum in HEPES buffered glucose (HBG) at $\mathrm{pH} 7.4$ was determined by the detection of residual free peptide in the supernatant after incubation and centrifugation of the MOF suspensions (Figures 2a, 2b, 2d, 3, S17, S19, Scheme $\mathrm{S} 1)$. An exemplary movie demonstrating the binding of $\mathrm{H}_{6}$-A647N to HKUST-1 MOF NPs visualized by decoloration of the supernatant after centrifugation is provided as supporting material for download. The exclusive reduction of $\mathrm{H}_{6}$-Acr (in contrast to $\mathrm{A}_{6}$-Acr) in the supernatant, illustrated by the discrete diminution of the $\mathrm{H}_{6}$-Acr peak in the RP-HPLC chromatograms, represents qualitative evidence for the histidine-dependent interaction with all three investigated MOF species (Figure $2 \mathrm{~b}$ ). The peptide- specific binding was also verified by zeta potential measurements (Figure 2c) showing a significant shift towards neutrality caused by the His-tag containing derivatives only. Quantitative determination of binding as a function of histidine residues, i.e. number of Lewis base units $\left(\mathrm{H}_{\mathrm{o}}\right.$, $\mathrm{H}_{3}, \mathrm{H}_{6}$ ) was carried out by photometric quantification of residual free peptide using a UV-photometer (Figure $2 \mathrm{~d}$ ). The amount of bound $\mathrm{H}_{3}$ - and $\mathrm{H}_{6}$-peptides increased with increasing amounts of MOFs, but binding of the $\mathrm{H}_{\mathrm{o}}$ derivative, corresponding to no histidine residue, was generally negligible. Notably, in case of all three MOFs significantly higher peptide binding was observed with higher number of histidines $\left(\mathrm{H}_{\mathrm{o}}\right.$ vs. $\mathrm{H}_{3}$ and $\mathrm{H}_{3}$ vs. $\left.\mathrm{H}_{6}\right)$.

a)

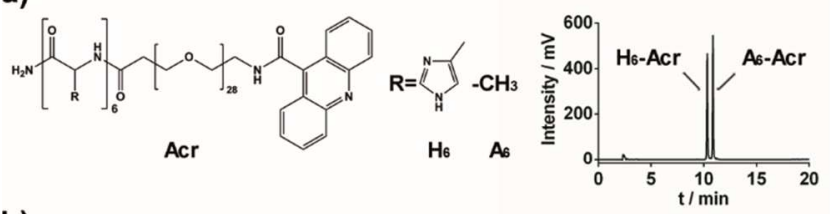

b)
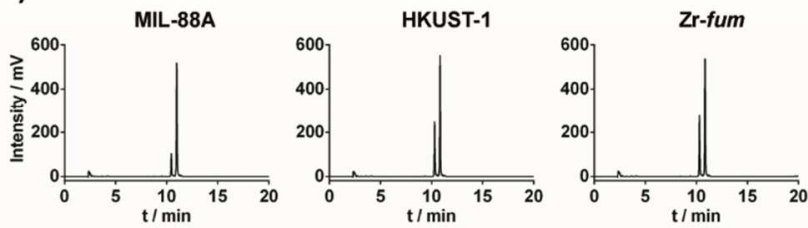

c)

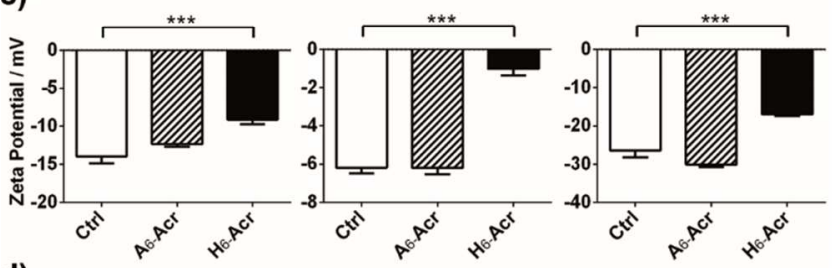

d)

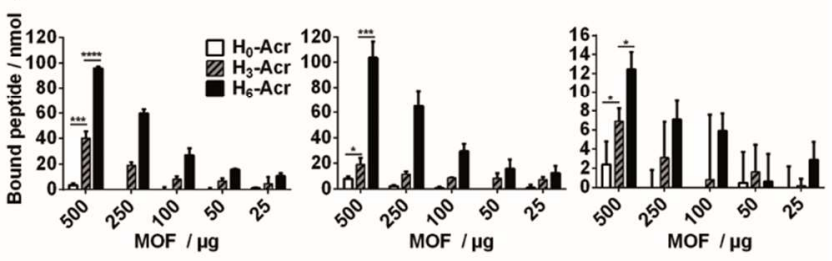

Figure 2. Acridine (Acr) peptide binding to MIL-88A (left), HKUST-1 (middle) and $\mathrm{Zr}$-fum (right) particles in HEPES buffered glucose (HBG) at $\mathrm{pH}$ 7.4. a) Chemical structure and control chromatogram of model compounds $\mathrm{H}_{6}$-Acr, $\mathrm{A}_{6}$-Acr. b) Peptide binding $\left(\mathrm{H}_{6}\right.$ vs. $\left.\mathrm{A}_{6}\right)$ by detection of reduced free peptides in the supernatant (RP-HPLC, $\lambda=360 \mathrm{~nm}$ ). c) Effect of peptide binding on zeta potential. d) Quantitative determination of bound peptides $\mathrm{H}_{\mathrm{o}}$ (white), $\mathrm{H}_{3}$ (pattern), $\mathrm{H}_{6}$ (black) as difference to photometrically quantified free peptides in the supernatant $(\lambda=360 \mathrm{~nm})$ using a UV-photometer. Please note that the scaling of $y$-axes is accommodated to the different binding capacities: $\mathbf{0 - 1 2 0}$ nmol peptide in case of MIL-88A and HKUST-1, o-16 nmol peptide in case of Zr-fum.

This correlation was additionally confirmed for Zr-fum via fluorescence spectroscopy by using FITC labeled peptides $\left(\mathrm{H}_{\mathrm{o} / 3 / 6}-\mathrm{FITC}\right)$ (Figure S19). Excessive addition of imidazole decreased binding of $\mathrm{H}_{6}$-FITC to levels of $\mathrm{H}_{\mathrm{o}}$ FITC, suggesting competition of histidine and free imidazole for coordinative interaction with the MOF surface, 
similar to the elution of His-tagged proteins from a nickel-column in immobilized-metal ion chromatography purifications. Comparing $\mathrm{H}_{6}$-tag binding to $500 \mu \mathrm{g} \mathrm{MOF}$ NPs, HKUST-1 achieved the highest binding (104 nmol), followed by MIL-88A (96 nmol) and $\mathrm{Zr}$-fum (12 nmol) which is consistent with reported metal ion affinities $\left(\mathrm{Cu}^{2+}>\mathrm{Fe}^{3+}, \mathrm{Zr}^{4+}\right)$ for His-tags ${ }^{41}$. A time course experiment (Figure $3 \mathrm{~b}$ ) revealed stable association of $\mathrm{Zr}-\mathrm{fum} / \mathrm{H}_{6}{ }^{-}$ A647N for 24 h at $\mathrm{pH} 7.4$ and rapid partial ( $\mathrm{pH}$ ) or complete $\left(\mathrm{pH}_{3}\right)$ release upon acidification. This is consistent with the hypothesis of unprotonated histidines acting as Lewis base and being responsible for binding (Figure 2a). We suggest that the incomplete detachment at $\mathrm{pH} 5$ is caused by a lowered $\mathrm{pK}_{\mathrm{a}}$ of the imidazole group due to metal ion binding ${ }^{58}$ and an equilibrium between protons and metal ions competing for histidine interactions.

a)
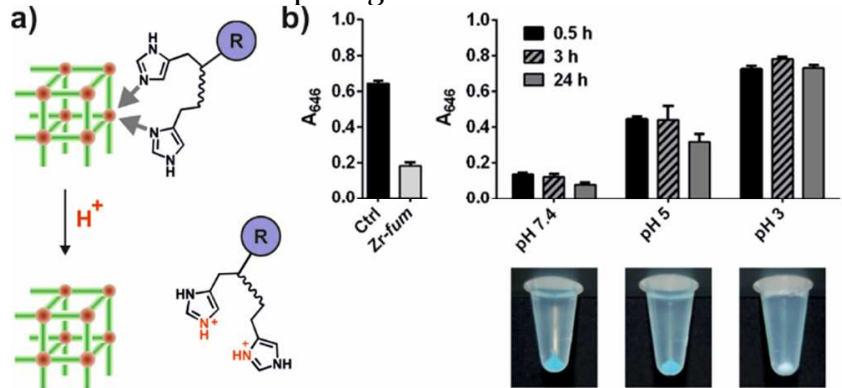

Figure 3. $\mathrm{pH}$ dependent stability of $\mathrm{H}_{6}$-tag binding to $\mathrm{Zr}$ fum NPs. a) Schematic illustration of acidic detachment due to histidine protonation. b) Experimental data obtained by photometric determination $(\lambda=646 \mathrm{~nm})$ of free $\mathrm{H}_{6}-\mathrm{A} 647 \mathrm{~N}$ in the supernatant after centrifugation. Left: $\mathrm{Zr}$-fum NPs were loaded with $\mathrm{H}_{6}-\mathrm{A} 647 \mathrm{~N}$ at $\mathrm{pH} 7.4$ for $15 \mathrm{~min}$, centrifuged and the supernatant was analyzed; Ctrl illustrates absorbance of free peptide in a sample without MOF NPs. Right: MOF NP suspensions were acidified to a defined $\mathrm{pH}$ and incubated for indicated times before centrifugation and analysis of the supernatant. Reaction tubes below show the MOF pellets of the same samples after $24 \mathrm{~h}$ at $\mathrm{pH} 7.4$ (left), $\mathrm{pH} 5$ (middle), $\mathrm{pH} 3$ (right) and centrifugation; decoloration of the pellet due to acidic $\mathrm{H}_{6}-\mathrm{A} 647 \mathrm{~N}$ detachment at $\mathrm{pH}_{3}$ can be observed.

Fluorescence Correlation Spectroscopy (FCS). Using FCS the binding of fluorescently labeled $\mathrm{H}_{6}$-tags to MOF particles was measured at low concentrations with singlemolecule sensitivity (Figure 4, S18). Figure 4 (upper left) and Figure $\mathrm{S}_{1} 8$ show a significant increase in the autocorrelation amplitude after addition of all three MOF species, indicating a reduction of the $\mathrm{H}_{6}$-tag number concentration most likely due to multiple binding to MOF NPs. In case of MIL-88A and HKUST-1 (Figure S18), however, no change in the characteristic correlation decay time could be detected. We attribute this to the known phenomenon of MOF induced fluorescence quenching ${ }^{59,60}$ as well as rather large effective particle sizes, in particular of HKUST-1, resulting from aggregation, which both can cause a decline of detectable tags after binding. For $\mathrm{Zr}$ fum NPs several key observations could be made (Figure 4). Free $\mathrm{H}_{6}$-tags (grey) showed fast single molecule diffusion prior to NP addition (Figure 4, lower left). After addition of $\mathrm{Zr}$-fum NPs at $\mathrm{pH} 7.4$ (orange) the collective diffusion was shifted towards higher diffusion times revealing
$\mathrm{H}_{6}$-tag binding to $\mathrm{Zr}$-fum NPs. Following acidification (green) the diffusion rate increased relative to the $\mathrm{pH} 7.4$ measurement indicating partial detachment of His-tags from the MOF NP surface, due to the protonation of histidines.
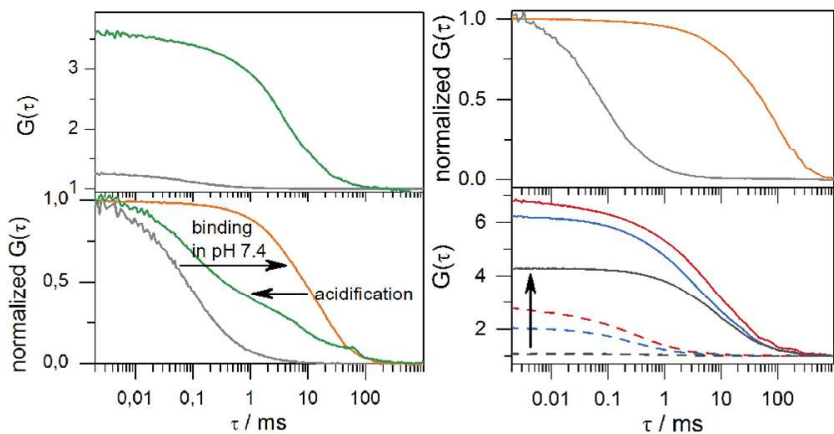

Figure 4. Investigation of $\mathrm{Zr}-\mathrm{fum} / \mathrm{H}_{6}-\mathrm{A} 647 \mathrm{~N}$ interaction by fluorescence correlation spectroscopy (FCS). Upper left: FCS time correlation functions of $\mathrm{H}_{6}-\mathrm{A} 647 \mathrm{~N}$ before (grey) and after $\mathrm{Zr}$-fum NP addition (green). Lower left: Normalized time correlation functions of binding of $\mathrm{H}_{6}-\mathrm{A} 647 \mathrm{~N}$ at $\mathrm{pH} 7.4$ (orange) and release upon acidification (green); free $\mathrm{H}_{6}$ A647N (grey). Upper right: Normalized time correlation functions of measurements in DMEM (10 \% FBS) of free $\mathrm{H}_{6}$ $\mathrm{A} 647 \mathrm{~N}$ (grey) and $\mathrm{Zr}-$ fum $/ \mathrm{H}_{6}-\mathrm{A} 647 \mathrm{~N}$ (orange). Lower right: fluorescence cross correlation spectroscopy (FCCS) measurements of $\mathrm{H}_{6}$-GFP (blue) and $\mathrm{H}_{6}$-Tf* (red) in $\mathrm{HBG}$ pH 7.4 before (dotted) and after (solid) $\mathrm{Zr}$-fum addition. Cross correlation before (dotted grey) and after (solid grey) $\mathrm{Zr}$-fum addition.

Importantly, $\mathrm{H}_{6}$-tag association with $\mathrm{Zr}$-fum NPs remained stable after dilution in DMEM medium containing $10 \%$ fetal bovine serum (FBS), confirming the suitability for use under cell culture conditions (Figure 4, upper right). Finally, two His-tagged proteins with distinct fluorescence spectra (recombinant eGFP with genetically encoded His-tag: $\mathrm{H}_{6}$-GFP, and human transferrin chemically conjugated with a $\mathrm{H}_{6}$-tag and Atto647N label: $\mathrm{H}_{6}-$ $\mathrm{Tf}^{*}$ ) were used for fluorescence cross correlation spectroscopy (FCCS) measurements to investigate simultaneous binding of both entities to single particles (Figure 4, lower right). In a solution containing equimolar amounts of both proteins the cross correlation showed high coincidence of $\mathrm{H}_{6}$-GFP and $\mathrm{H}_{6}$-Tf* after addition of $\mathrm{Zr}$-fum NPs (solid grey), which demonstrated binding of different His-tagged proteins to the same $\mathrm{Zr}$-fum particles. Importantly both FCS and FCCS experiments revealed the colloidal stability of the MOF NPs. Additionally, the framework stability of the particles prior to and after functionalization under aqueous conditions was investigated by XRD measurements (Figures $\mathrm{S}_{3}-\mathrm{S}_{5}$ ). The experiments showed the nearly unchanged crystallinity of all samples under each tested condition. In case of $\mathrm{Zr}$-fum MOF NPs this was also confirmed by SEM and DLS measurements, exhibiting no observable change in morphology of dried particles and moderate effect on hydrodynamic size of dispersed particles upon modification with $\mathrm{H}_{6}$ Acr in HBG pH 7.4 (Figures $\mathrm{S}_{2}$ and $\mathrm{S}_{16}$ ). 
Cellular uptake of model peptides and proteins with MOF NPs. To assess the potential of MOF NPs to mediate cellular internalization of biomacromolecules, $\mathrm{H}_{6}$-Carboxyfluorescein $\left(\mathrm{H}_{6}-\mathrm{CF}\right)$, recombinant eGFP with genetically encoded His-tag $\left(\mathrm{H}_{6}\right.$-GFP) and chemically Histagged and ATTo647N labeled human transferrin $\left(\mathrm{H}_{6}-\mathrm{Tf}^{*}\right)$ were used as fluorescent model compounds. Based on the photometrical analysis of His-tag binding to the three MOF species (Figure 2d), the His-tagged functional units

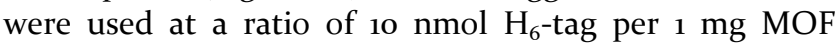
which is considerably below the determined binding capacities of $192 \mathrm{nmol} / \mathrm{mg}$ MIL88A, $208 \mathrm{nmol} / \mathrm{mg}$ HKUST-1 and $24 \mathrm{nmol} / \mathrm{mg} \mathrm{Zr-fum}$. First, cell viability of HeLa cells after incubation with different amounts of all three MOF NPs and different His-tags for $48 \mathrm{~h}$ was evaluated by MTT-assay (Figure S20). MIL-88A, Zr-fum, and the tested His-tags $\mathrm{H}_{6}-\mathrm{CF}, \mathrm{H}_{6}$-GFP and $\mathrm{H}_{6}$-Tf, were very well tolerated. HKUST-1 exhibited considerable cytotoxicity, which could be avoided by shortening the incubation time with cells to $2 \mathrm{~h}$ followed by medium exchange, which deleted observable effects on metabolic activity at the endpoint evaluation after $48 \mathrm{~h}$ (Figure S2ob). Next, cellular uptake of the different MOF NPs after functionalization with the $\mathrm{H}_{6}$-tagged fluorescent dye $\mathrm{H}_{6}$-CF or $\mathrm{H}_{6}$-GFP was investigated. For prefunctionalization by coordinative selfassembly, His-tags and MOF NPs were mixed at a final concentration of $10 \mu \mathrm{M} \mathrm{H}_{6}$-tag and $1 \mathrm{mg} / \mathrm{ml} \mathrm{MOF}$ in $\mathrm{HBG}$ buffer (ratio of $10 \mathrm{nmol}_{6}$-tag per $1 \mathrm{mg} \mathrm{MOF}$ ) and incu-
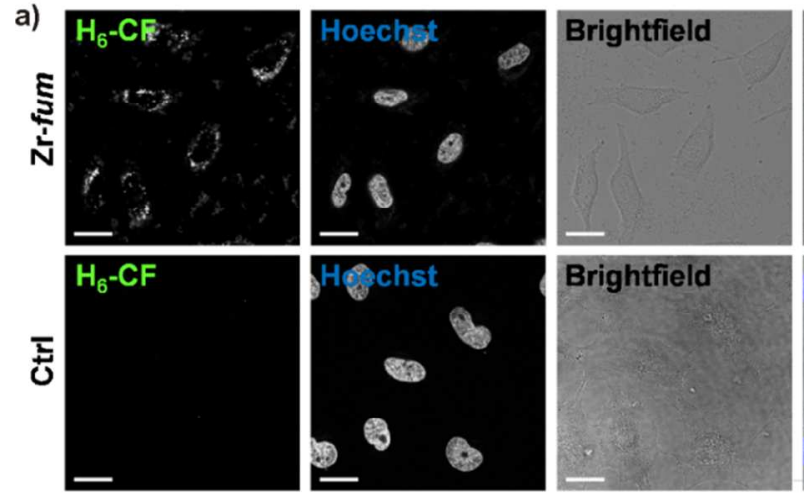

bated for $15 \mathrm{~min}$ at room temperature. Cells were then incubated with the different functionalized MOF NPs for $24 \mathrm{~h}$ in medium at a concentration of $0.1 \mathrm{mg} / \mathrm{mL} \mathrm{MOF}$ corresponding to $1 \mu \mathrm{M}$ His-tag, followed by flow cytometry and confocal laser scanning microscopy (CLSM) (Figure 5, S21, S22a, S23-S26). MIL-88A and HKUST-1 MOF NPs contained huge particles with a tendency to aggregate (Figure $\mathrm{S}_{1}, \mathrm{~S}_{10}-\mathrm{S}_{13}$ ) and showed quenching effects (Figure S18) resulting in poor detectability of cellular uptake (Figure S21). Compared to MIL-88A and HKUST-1, Zr-fum MOF NPs exhibit several favorable characteristics such as very narrow particle size distribution, uniform sphere morphology, low aggregation behavior, negligible fluorescence quenching and also good cellular tolerance. Thus despite their comparatively low His-tag binding capacity, they were selected to be used for further experiments. $\mathrm{Zr}$-fum $/ \mathrm{H}_{6}-\mathrm{CF}$ showed cellular uptake in CLSM (Figure 5a, left) and flow cytometry (Figure 5a, right). Additional z-stacks of CLSM images can be found in Figures $\mathrm{S}_{23}$ and $\mathrm{S}_{24}$. The mean fluorescence intensity (MFI, inset) of cells treated with $\mathrm{Zr}$-fum $/ \mathrm{H}_{6}-\mathrm{CF}$ increased 20fold compared to free $\mathrm{H}_{6}-\mathrm{CF}$. The cellular uptake of $\mathrm{Zr}$ fum $/ \mathrm{H}_{6}$-GFP alone is depicted in Figure $\mathrm{S}_{22} \mathrm{a}, \mathrm{S}_{25}$ and $\mathrm{S}_{2} 6$ showing 30-fold higher MFI values compared to free $\mathrm{H}_{6}-$ GFP. A 3 D reconstruction movie of a cell treated with $\mathrm{Zr}$ fum $/ \mathrm{H}_{6}$-GFP is provided as supporting material for download.

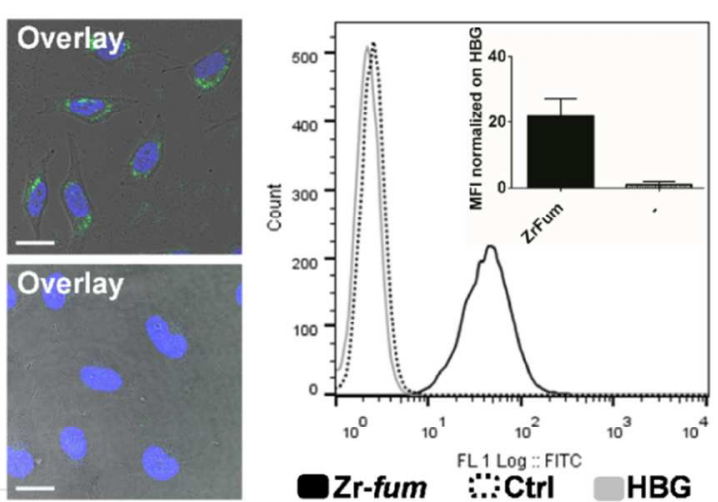

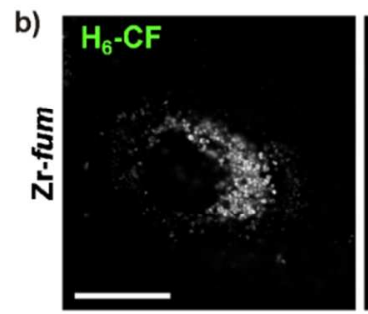
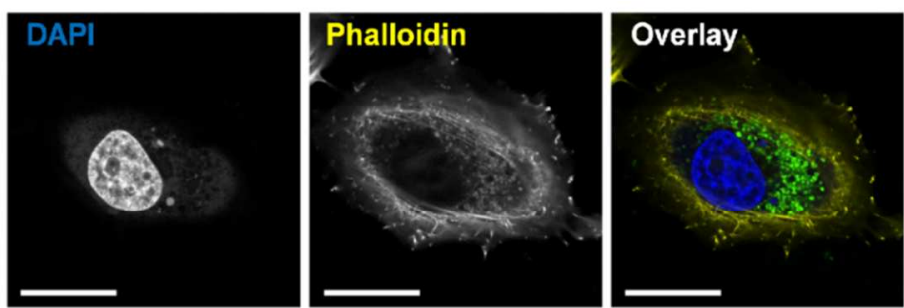

Figure 5. Cellular uptake of fluorescent peptide $\mathrm{H}_{6}$-CF mediated by $\mathrm{Zr}$-fum NPs. $\mathrm{H}_{6}$-CF was incubated with $\mathrm{Zr}$-fum MOF NPs for $15 \mathrm{~min}$ at room temperature in HBG for prefunctionalization by coordinative self-assembly. The functionalized particles were incubated with HeLa cells for $24 \mathrm{~h}$ at a concentration of $0.1 \mathrm{mg} / \mathrm{mL} \mathrm{Zr-fum} \mathrm{corresponding} \mathrm{to} 1 \mu \mathrm{M} \mathrm{H}_{6}-\mathrm{CF}$. Solutions containing $\mathrm{H}_{6}$-CF at same concentration but no Zr-fum NPs served as control (Ctrl). a) Confocal laser scanning microscopy (CLSM, left) and flow cytometry (right) after incubation of HeLa cells with functional NPs Zr-fum/ $\mathrm{H}_{6}$-CF (Zr-fum, CLSM upper row, flow cytometry solid black), $\mathrm{H}_{6}$-CF control without Zr-fum NPs (Ctrl, CLSM lower row, flow cytometry dotted black) or HBG (flow cytometry grey). Mean fluorescence intensity (MFI) was normalized to HBG and is depicted in the inset. CLSM left to right: green fluorescence of $\mathrm{H}_{6}-\mathrm{CF}$, nuclear staining with Hoechst dye, brightfield image, overlay of all three channels. b) Enlarged CLSM image of a fixated HeLa cell after incubation with $\mathrm{Zr}-f u m / \mathrm{H}_{6}-\mathrm{CF}$. Left to right: green fluorescence of $\mathrm{H}_{6}-\mathrm{CF}$, nuclear staining with DAPI dye, actin staining with rhodamine-phalloidin, overlay of all three channels. Scale bar: $25 \mu \mathrm{m}$. Additional images can be found in the Supporting Information Figure S23 and S24. 
A distinct advantage of the self-assembly concept demonstrated here is the possible one-step multifunctionalization of MOF NPs by simultaneously mixing of different $\mathrm{H}_{6}$-tagged functional units with bare MOF NPs (Figure 1c). This procedure facilitates the creation of multifunctional MOF NPs with various stoichiometric ratios as required for optimization of spatio-temporal codelivery into cells. As the simultaneous assembly of $\mathrm{H}_{6}$ GFP and $\mathrm{H}_{6}$-Tf $f^{*}$ with $\mathrm{Zr}$-fum MOF NPs had been confirmed by FCCS measurements (Figure 4, lower right), HeLa cells were subjected to these double-functionalized particles $\left(\mathrm{Zr}-\mathrm{fum} / \mathrm{H}_{6}-\mathrm{GFP}+\mathrm{H}_{6}-\mathrm{Tf}^{*}\right)$ for $24 \mathrm{~h}$ at a concentration of $0.1 \mathrm{mg} / \mathrm{mL}$ MOF corresponding to $0.5 \mu \mathrm{M} \mathrm{H}_{6}$-GFP and $\mathrm{H}_{6}-\mathrm{Tf}^{*}$, followed by investigation of the internalization (Figures 6, S22b). Considerable co-localization of $\mathrm{H}_{6-}$ GFP and $\mathrm{H}_{6}-\mathrm{Tf}^{*}$ could be observed (Figure 6a, upper row and $6 \mathrm{~b}$ ). In contrast to free $\mathrm{H}_{6}$-GFP, free $\mathrm{H}_{6}$-Tf ${ }^{*}$ was also taken up by the cells without the addition of $\mathrm{Zr}$-fum MOF NPs to a certain extent (Figure 6a, lower row). This can be explained by the fact that HeLa cells express the transferrin receptor (Figure S29), thus enabling receptormediated uptake of free $\mathrm{H}_{6}-\mathrm{Tf}^{*}$. However, despite the MOF-independent uptake route of $\mathrm{H}_{6}-\mathrm{Tf}^{*}$, association with $\mathrm{Zr}$-fum resulted in 5 -fold higher internalization, confirming an additional boost due to NP mediated uptake. Additional z-stacks of CLSM images can be found in Figures S27 and S28. Looking at the intracellular distribution of fluorescent peptides and proteins internalized via $\mathrm{Zr}$-fum MOF NPs in detail, the spotty arrangement indicates high vesicular entrapment and suggests endosomal escape being a hurdle for cytosolic delivery.
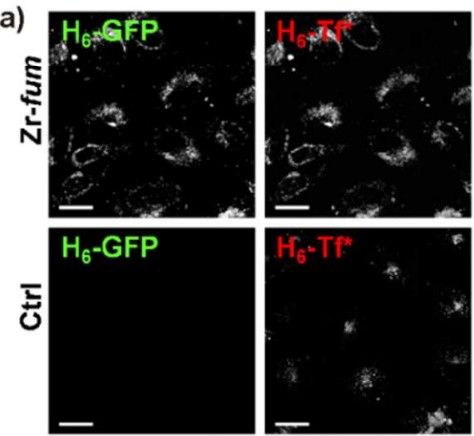

b)

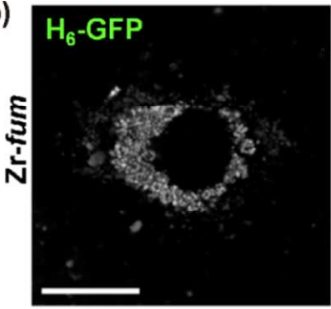

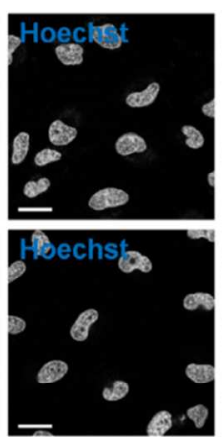
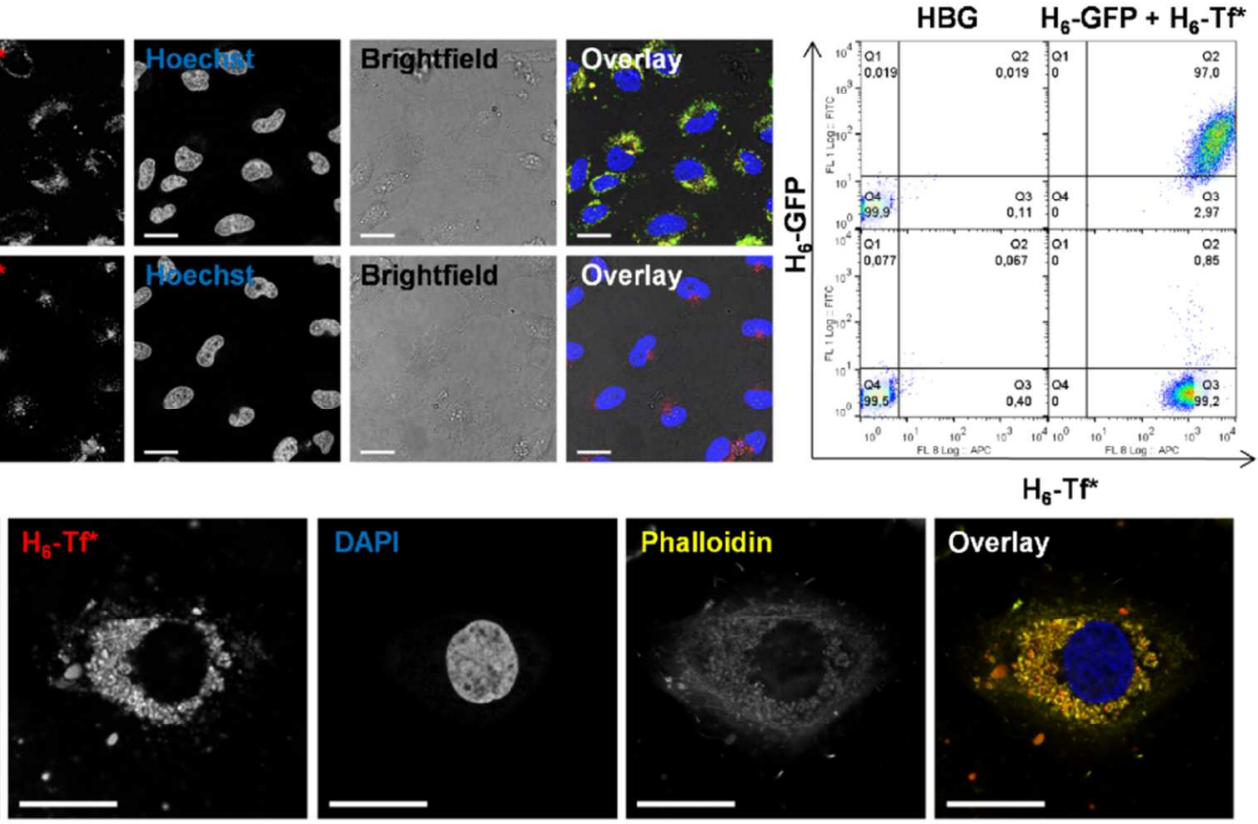

$\mathrm{H}_{6}-\mathrm{Tf}^{*}$

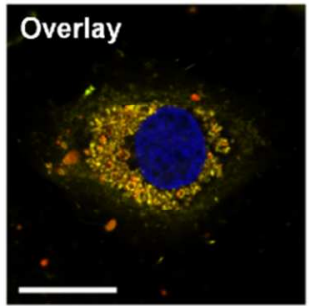

Figure 6. Simultaneous cellular uptake of fluorescent proteins $\mathrm{H}_{6}$-GFP and $\mathrm{H}_{6}-\mathrm{Tf} f^{\star}$ mediated by Zr-fum NPs. An equimolar mixture of $\mathrm{H}_{6}$-GFP and $\mathrm{H}_{6}$-Tf* was incubated with Zr-fum MOF NPs for 15 min at room temperature in HBG for prefunctionalization by coordinative self-assembly. The double functionalized particles were incubated with HeLa cells for $24 \mathrm{~h}$ at a concentration of o.1 mg/mL Zr-fum corresponding to $0.5 \mu \mathrm{M} \mathrm{H}_{6}$-GFP and $\mathrm{H}_{6}$-Tf*. Solutions containing $\mathrm{H}_{6}$-GFP and $\mathrm{H}_{6}-\mathrm{Tf}^{*}$ at same concentration but no Zr-fum NPs served as control (Ctrl). a) Cellular uptake of Zr-fum $/ \mathrm{H}_{6}-\mathrm{GFP}+\mathrm{H}_{6}-\mathrm{Tf}^{*}$ (upper row) or control without MOF NPs (lower row). CLSM left to right: green fluorescence of $\mathrm{H}_{6}$-GFP, red fluorescence of $\mathrm{H}_{6}$-Tf ${ }^{*}$, nuclear staining with Hoechst dye, brightfield picture, overlay of all four channels, yellow color indicates co-localization of $\mathrm{H}_{6}-\mathrm{GFP}$ and $\mathrm{H}_{6}$-Tf* . Flow cytometry analysis: $\mathrm{HBG}$ (left) or $\mathrm{H}_{6}-\mathrm{GFP}+\mathrm{H}_{6}-\mathrm{Tf}^{*}$ (right) with Zr-fum MOF NPs (upper row) or Ctrl without MOF NPs (lower row). b) Enlarged CLSM image of a fixated HeLa cell after incubation with Zr-fum $/ \mathrm{H}_{6}-\mathrm{GFP}+\mathrm{H}_{6}-\mathrm{Tf}^{*}$. Left to right: green fluorescence of $\mathrm{H}_{6}-\mathrm{GFP}$, red fluorescence of $\mathrm{H}_{6}-\mathrm{Tf}^{*}$, nuclear staining with DAPI dye, actin staining with rhodamine-phalloidin, overlay of all four channels. Scale bar: $25 \mu \mathrm{m}$. Additional images can be found in the Supporting Information Figure S27 and S28 and a ${ }_{3} \mathrm{D}$ reconstruction movie of a cell treated with $\mathrm{Zr}-\mathrm{fum} / \mathrm{H}_{6}-\mathrm{GFP}$ is provided as supporting material for download.

Endocytosis mechanism. The cellular uptake pathway of $\mathrm{Zr}-\mathrm{fum} / \mathrm{H}_{6}$-GFP NPs was investigated in an uptake experiment (Figure 7). HeLa cells were pre-incubated for 30 min at $4{ }^{\circ} \mathrm{C}$, to reduce cellular metabolism and block energy dependent processes, or with various concentrations of the individual endocytosis inhibitors chlorpromazine (clathrin-mediated endocytosis), amiloride (macropinocytosis) and genistein (caveolae-mediated endocytosis) to discriminate the particular endocytotic routes. Afterwards the cells were subjected to $\mathrm{Zr}-f u m / \mathrm{H}_{6}$ GFP NPs at a concentration of $0.1 \mathrm{mg} / \mathrm{mL}$ MOF NPs corresponding to $1 \mu \mathrm{M} \mathrm{H}_{6}$-GFP for $2 \mathrm{~h}$, followed by flow cytometric analysis in acidified PBS ( $\mathrm{pH} 4,10 \%$ FBS) to quench the extracellular fluorescence. The results clearly show, that the NPs are internalized via an energy dependent process. Pre-incubation with amiloride showed the 
greatest inhibitory effect which suggests macropinocytosis is having major contribution to the uptake of $\mathrm{Zr}$ fum $/ \mathrm{H}_{6}$-GFP nanoparticles. Since some effect of genistein was observed, caveolae mediated uptake might also be involved to a minor extent. A recent study investigated the endocytosis mechanisms of UiO-66 $\left(\mathrm{Zr}^{4+} /\right.$ terephthalate) MOF NPs ${ }^{61}$. Consistently, the cellular uptake of UiO-66 was also identified to be an energy dependent process with distinct involvement of macropinocytosis, however also major contribution of clathrin-mediated endocytosis was found.

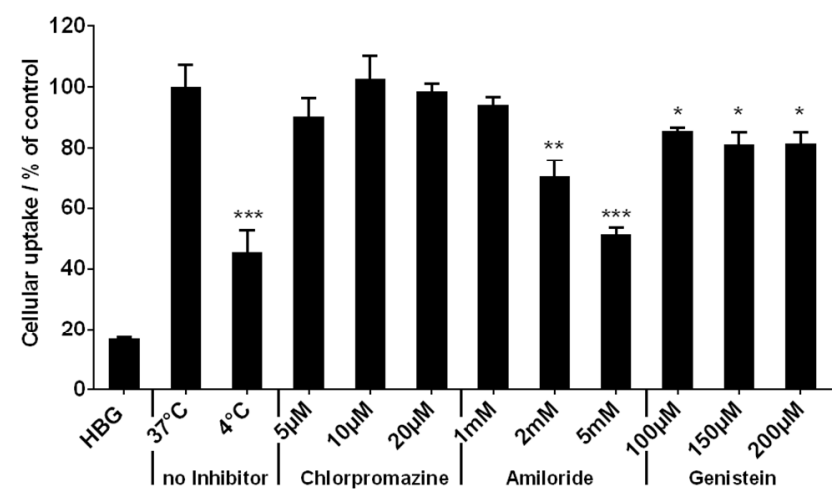

Figure 7. Evaluation of endocytosis inhibition of $\mathrm{Zr}$ fum $/ \mathrm{H}_{6}$-GFP nanoparticles. Pre-Incubation of HeLa cells with different inhibitors or at $4{ }^{\circ} \mathrm{C}$ for $30 \mathrm{~min}$, followed by incubation with $\mathrm{Zr}-\mathrm{fum} / \mathrm{H}_{6}-\mathrm{GFP}$ for $2 \mathrm{~h}$ at $37^{\circ} \mathrm{C}$ or $4{ }^{\circ} \mathrm{C}$. Flow cytometric analysis was carried out in PBS ( $\mathrm{pH} 4.0$ ) to quench the extracellular fluorescence. Cellular uptake was determined as MFI. Data are presented as \% cellular uptake normalized to uptake of $\mathrm{Zr}-\mathrm{fum} / \mathrm{H}_{6}$-GFP NPs at $37^{\circ} \mathrm{C} \pm \mathrm{SD}(n=3)$.

Transduction of biologically active peptides and proteins. To further evaluate the potential of $\mathrm{Zr}$-fum MOF NPs as carrier system for cytosolic cargo release, transduction of membrane impermeable bioactive proapoptopic peptides (Bak, Bad, KLK) and mitochondrial cytochrome $\mathrm{C}(\mathrm{CytC})$ protein was investigated and cell killing was used as reporter of successful cytosolic delivery. $\mathrm{H}_{6}$-tags were chemically conjugated to $\mathrm{CytC}$ or integrated at the $\mathrm{N}$-terminus of the peptide sequences derived from the $\mathrm{BH}_{3}$ domain of Bak and Bad proteins ${ }^{62}$ or the antibacterial and mitochondrial membrane-disruptive artificial peptide $\mathrm{KLK}^{63,64}$. Endogenous cellular CytC represents an essential part of the electron transfer chain in mitochondria but also a crucial player in the intrinsic mitochondrial apoptosis pathway after release into the cytosol $^{65}$. Several approaches for the intracellular delivery of exogenous $\mathrm{CytC}$, induction of apoptosis and cell killing have been reported before ${ }^{66-69}$. Notably, for the purification of $\mathrm{H}_{6}$-CytC (and $\mathrm{H}_{6}-\mathrm{Tf}^{*}$ ) carrying a $\mathrm{H}_{6}$-tag after chemical conjugation, immobilized metal-ion chromatography was used, which is based on the same principle as the binding to MOFs. The utilization of the same interaction for isolation and subsequent attachment to the carrier system is considered a very convenient and robust manufacturing process. Binding of the pro-apoptotic factors to Zr-fum NPs was confirmed by measuring the change of zeta potential upon addition of the MOFs (Figure S3oa). For biological evaluation, HeLa cells were treated with $\mathrm{Zr}-\mathrm{fum} / \mathrm{H}_{6}-\mathrm{Bak}, / \mathrm{H}_{6}-\mathrm{Bad}, / \mathrm{H}_{6}-\mathrm{KLK}$ or $/ \mathrm{H}_{6}-$ CytC (0.2 mg/mL Zr-fum and $10 \mu \mathrm{M}$ peptide or protein) for $48 \mathrm{~h}$. Cell viability was assessed by MTT assay and approx. $60 \%$ cell killing could be detected in case of all functionalized Zr-fum NPs (Figure 8).

Without the addition of MOF NPs all pro-apoptotic factors did not exhibit any detectable toxicity up to a concentration of $20 \mu \mathrm{M}$ (Figure S3ob). These findings indicate that, despite the bottleneck of vesicular entrapment, significant fractions of cargo molecules were able to escape and induce biological effects in the cytosol.
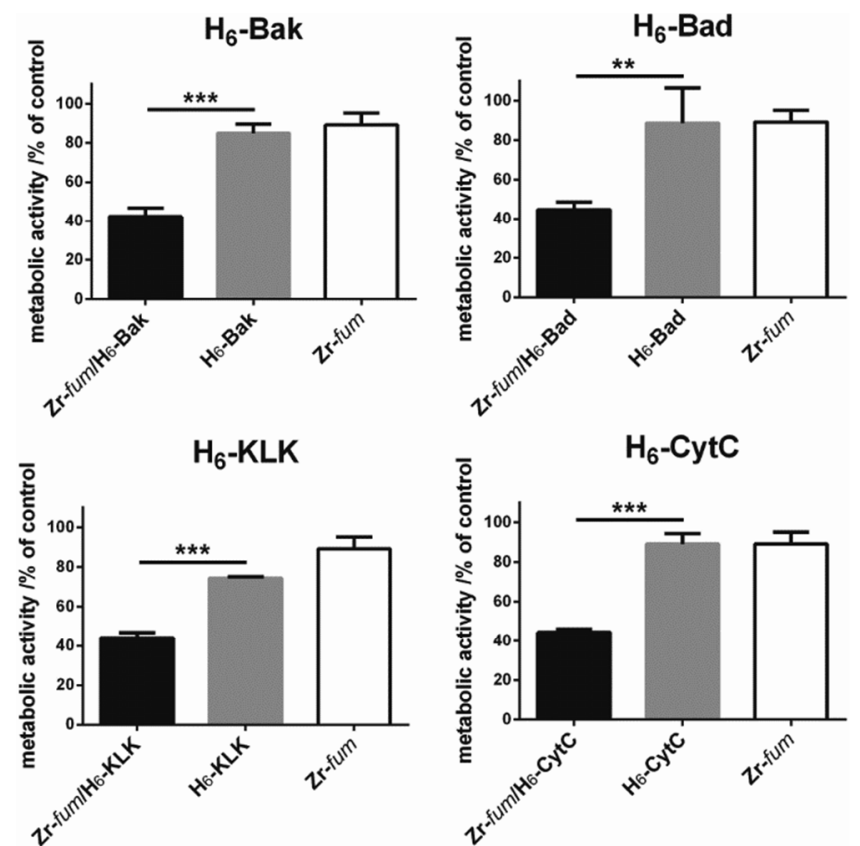

Figure 8. Intracellular transport of pro-apoptotic factors by $\mathrm{Zr}$-fum MOF NPs and induction of HeLa cell killing upon incubation for $48 \mathrm{~h}$. Final concentration of $\mathrm{H}_{6}-\mathrm{Bak}, \mathrm{H}_{6}-\mathrm{Bad}$, $\mathrm{H}_{6}-\mathrm{KLK}, \mathrm{H}_{6}-\mathrm{CytC}$ was $10 \mu \mathrm{M}$ (o.2 mg Zr-fum/10 nmol His-tag per $\mathrm{mL}$ medium). Data are presented as \% metabolic activity of control cells \pm SD $(n=3)$ (MTT assay).

\section{CONCLUSION}

In summary, the proposed coordinative interaction of functionalized His-tags with MOF NPs was successfully established, exhibiting His-tag length and MOF species dependent binding. The fact that all investigated MOF structures showed considerable $\mathrm{H}_{6}$-tag binding, despite their different metal components, provided flexibility for consideration of additional parameters and material characteristics (e.g. particle size distribution, aggregation behavior, fluorescence quenching and cytotoxicity) relevant for the intended purpose. The inherent properties of the individual compounds (His-tag containing functional units, MOF NPs) and the reversible nature of interaction account for the strength of the approach. Numerous available recombinant proteins already contain His-tags or they can readily be integrated in peptidic structures by conjugation. For biomedical applications, MOF NPs are promising materials due to their precise assembly of an 
enormous number of inorganic and organic molecular building blocks resulting in a highly variable chemical composition, porosity and degradability into their small building units. The MOF structural designability at the molecular level chemistry together with an extension of the functional unit library opens the perspective to generate a variety of "self-assembling multifunctional coordination particles" (SAMCOPs) by simple combinatorial and stoichiometric mixing. In this respect, this work presents a versatile functionalization concept of MOF NPs with great potential for co-delivery of proteins, drugs or other pharmacologically active agents, including those that can be adsorbed within the pore systems.

\section{METHODS}

Synthesis of MIL-88A.MIL-88A were synthesized using an approach based on the results of Chalati et al. ${ }^{52} \mathrm{FeCl}_{3} \mathrm{x}$ $6 \mathrm{H}_{2} \mathrm{O}(1.084 \mathrm{~g}, 4.01 \mathrm{mmol})$ and fumaric acid $(485 \mathrm{mg}$, $4.18 \mathrm{mmol})$ were given into water $(20 \mathrm{~mL})$. After $\mathrm{FeCl}_{3} \mathrm{x}$ $6 \mathrm{H}_{2} \mathrm{O}$ was completely dissolved, the reaction vessel was placed in a microwave reactor (Synthos 3000, Anton Paar). In addition to the reaction vessel, a reference vessel containing an aqueous solution of $\mathrm{FeCl}_{3} \times 6 \mathrm{H}_{2} \mathrm{O}(1.08 \mathrm{og}$, $20 \mathrm{~mL}$ ) and 2 vessels containing water $(20 \mathrm{~mL})$ were placed in the microwave reactor. The sample was heated in 30 sec to $80{ }^{\circ} \mathrm{C}$, stayed at $80{ }^{\circ} \mathrm{C}$ for $5 \mathrm{~min}$ and cooled down to room temperature in $1 \mathrm{~h}$.

Synthesis of HKUST-1. The synthesis of HKUST-1 was conducted following a method shown by Huo et al. ${ }^{47}$ $\mathrm{Cu}\left(\mathrm{NO}_{3}\right)_{2} \times 2.5 \mathrm{H}_{2} \mathrm{O}(70 \mathrm{mg}, 0.30 \mathrm{mmol})$ was dissolved in water $(6 \mathrm{~mL})$. Trimesic acid $(126 \mathrm{mg}, 0.60 \mathrm{mmol})$ was added to this solution under stirring. The reaction mixture was left stirring for $60 \mathrm{~min}$. Subsequently, the resulting product was washed via centrifugation $(15 \mathrm{~min}$, $8750 \mathrm{rpm})$. The supernatant was removed and the precipitated nanoparticles were dispersed in ethanol $(6 \mathrm{~mL})$. This washing cycle was repeated three times to yield the final product.

Synthesis of Zr-fum. Zr-fum were synthesized using an approach based on the results of Wißmann et al. ${ }^{48} \mathrm{ZrCl}_{4}$ (120.4 mg, $0.52 \mathrm{mmol}$ ) and fumaric acid (180.1 mg, $1.54 \mathrm{mmol}$ ) were given into a glass vessel $(25 \mathrm{~mL})$. A mixture of water $(10 \mathrm{~mL})$ and formic acid $(975 \mu \mathrm{L})$ was added to the glass reactor. After sealing the reactor the dispersion was placed in an oven $\left(120^{\circ} \mathrm{C}\right)$ for $24 \mathrm{~h}$. Subsequently, the reaction mixture was cooled down to room temperature followed by separation into 8 equal portions. The nanoparticle dispersions were washed in a first step via centrifuging (4 min, $14000 \mathrm{rpm}$ ) and subsequent redispersion in water $(8 \times 1.5 \mathrm{~mL})$ under sonication. The samples were further washed in three additional washing cycles comprising centrifugation (4 min, $14000 \mathrm{rpm}$ ), removal of the supernatant, and redispersion of the remaining nanoparticles in ethanol $(8 \times 1.5 \mathrm{~mL})$. Afterwards, the 8 dispersions were reunified.

Preparation of MOF suspension in HBG. MOF suspensions in HBG were always freshly prepared prior to performing the experiment. The necessary amount of MOF material in ethanol was centrifuged (10 min, $10000 \mathrm{rpm})$, and the supernatant was removed. The MOF pellet was resuspended in HBG ( $\mathrm{pH} 7.4$ ) at a final concentration of 5 or $10 \mathrm{mg} / \mathrm{mL}$ by continuous pipetting, followed by $10 \mathrm{~min}$ sonication.

Investigation of peptide binding $\left(\mathrm{A}_{6}, \mathrm{H}_{6}\right)$ by $\mathrm{RP}$ HPLC. $3 \mu \mathrm{L}$ of a solution containing equimolar amounts of $\mathrm{H}_{6}$-Acr and $\mathrm{A}_{6}$-Acr ( $5 \mathrm{mM}$ ) in HBG ( $\mathrm{pH}$ 7.4) were added to $47 \mu \mathrm{L}$ HBG in a $1.5 \mathrm{~mL}$ reaction tube. $100 \mu \mathrm{L}$ of MOF suspension $(5 \mathrm{mg} / \mathrm{mL}$ in $\mathrm{HBG}, \mathrm{pH} 7.4$ ) were added and vortexed briefly. As control, $100 \mu \mathrm{L}$ HBG without MOF particles were added to an analogous sample. The mixtures were incubated at room temperature for $15 \mathrm{~min}$ under shaking and centrifuged for $10 \mathrm{~min}$ at $13400 \mathrm{rpm}$. Subsequently, $120 \mu \mathrm{L}$ of the supernatant were transferred into HPLC sample vials. RP-HPLC analysis was carried out using a YMC Pack Pro C18 RS column (250 x $4.6 \mathrm{~mm}$ ) connected to a VWR Hitachi Chromaster HPLC system (5160 pump module, 5260 auto sampler, 5310 column oven, 5430 diode array detector). $10 \mu \mathrm{L}$ of the samples were injected and a gradient from $5 \%$ acetonitrile (o.1\% TFA) to $100 \%$ acetonitrile (o.1 \% TFA) over 15 min was used for the analysis. Acridine containing compounds were detected photometrically at $360 \mathrm{~nm}$.

Zeta potential measurements of MOF nanoparticle functionalization. $3 \mathrm{nmol}_{6}$-Acr or $\mathrm{A}_{6}$-Acr were diluted in HBG ( $\mathrm{pH} \mathrm{7.4)}$ buffer. In case of pro-apoptotic peptides and CytC $5 \mathrm{nmol}$ were used. $100 \mu \mathrm{g}$ MOF NPs $(5 \mathrm{mg} / \mathrm{mL}$, HBG $\mathrm{pH}$ 7.4) were added (final volume $30 \mu \mathrm{L}$ ) and samples were incubated at room temperature for $15 \mathrm{~min}$ with shaking. Shortly before the measurement in a folded capillary cell (DTS1070), samples were diluted to a final MOF concentration of $0.1 \mathrm{mg} / \mathrm{mL}$. Zeta potential was measured by electrophoretic laser-light scattering using a Zetasizer Nano ZS (Malvern Instruments, Worcestershire, U.K.). Zeta potentials were calculated by the Smoluchowski equation, each sample was measured 3 times with 10 to 30 subruns at $25^{\circ} \mathrm{C}$.

Quantitative determination of $\mathrm{H}_{\mathbf{0}^{-}}, \mathrm{H}_{3^{-}}, \mathrm{H}_{6}$-Acr binding to MOF NPs. A solution containing a total amount of $130 \mathrm{nmol}$ oligopeptide-based structure to be examined was prepared in HBG. The required amount of $10 \mathrm{mg} / \mathrm{mL}$ MOF nanoparticles dispersed in HBG was added featuring a total volume of $1 \mathrm{~mL}$. Right after the addition of the MOF nanoparticles, samples were briefly vortexed. After subsequent incubation $\left(15 \mathrm{~min}, 25^{\circ} \mathrm{C}\right.$, $600 \mathrm{rpm}$ ) and centrifugation ( $5 \mathrm{~min}, 14000 \mathrm{rpm}) 100 \mu \mathrm{L}$ of supernatant were collected and photometrically measured at $360 \mathrm{~nm}$ against HBG as a blank. For each examined oligopeptide-based structure, a control of $130 \mathrm{nmol}$ peptide without MOF in a total volume of $1 \mathrm{~mL}$ was also prepared and measured $(n=3)$. To obtain the amount of bound peptide, the absorption of the supernatant - representing the amount of peptide that remained in solution and thereby unbound by the MOF - was subtracted from the average absorption of the MOF free control: A(bound) $=\mathrm{A}($ control $)-\mathrm{A}$ (supernatant $)$. Final binding values were calculated as follows, $\%$ (bound $)=\mathrm{A}($ bound $) / \mathrm{A}($ control $) \mathrm{x}$ 10o. The average of \% bound determined by three independent measurements \pm SD was plotted.

Investigation of binding stability of $\mathrm{H}_{6}$-tags to $\mathrm{Zr}$ fum and $\mathrm{pH}$ dependent release. In order to evaluate 
the stable binding and extent of acidic release of His-tags and $\mathrm{Zr}$-fum MOF NPs over a longer period, Zr-fum NPs in HBG were loaded with $\mathrm{H}_{6}-\mathrm{A} 647 \mathrm{~N}$. $50 \mu \mathrm{L}$ of the freshly prepared $\mathrm{Zr}$-fum NPs were diluted in $\sim 500 \mu \mathrm{L} \mathrm{HBG} \mathrm{pH} 7.4$ (depending on the amount of $\mathrm{HCl}$ added to the sample in the next step), followed by addition of $4 \mu \mathrm{L} 1 \mathrm{mM} \mathrm{H}_{6}$ A647N. The HBG volume therefore slightly varied in order to always allow for equal final sample volumes of $500 \mu \mathrm{L}$. Samples were briefly vortexed and incubated under agitation for $15 \mathrm{~min}\left(25^{\circ} \mathrm{C}\right.$, $600 \mathrm{rpm}$, light protection). Afterwards, samples were acidified to $\mathrm{pH}_{3}, \mathrm{pH}_{5}$ and $\mathrm{pH} 7.4$ by addition of $9.2 \mu \mathrm{L}, 4.5 \mu \mathrm{L}$ or $\mathrm{o} \mu \mathrm{L} 1 \mathrm{M} \mathrm{HCl}$ respectively. After $0.5 \mathrm{~h}, 3 \mathrm{~h}$ and $24 \mathrm{~h}$, the respective samples were centrifuged ( $5 \mathrm{~min}, 14000 \mathrm{rpm})$. The presence of free dye in the supernatant was determined photometrically at $646 \mathrm{~nm}(\mathrm{n}=3)$. Independent samples were used for each time point.

Fluorescence Correlation Spectroscopy (FCS). The non-fluorescent MOF nanoparticles are not detectable by the FCS unless fluorescently labeled His-tags are attached to the NPs. Thus a shift to higher diffusion times of the correlation curve after addition of NPs to fluorescently labeled His-tags certifies the binding of His-tags to the NPs surface. Normalization of autocorrelation curves helps to clearly visualize that the autocorrelation function of the MOF/His-tag is shifted towards higher correlation times with respect to the free His-tag molecules. Dualcolor fluorescence Cross-Correlation Spectroscopy (FCCS) allows for a comparison between spectrally separated channels to extract codiffusion events that reflect interactions between differently labeled molecules. ${ }^{70,71}$ For FCS and FCCS measurements, an Axiovert 200 microscope with a ConfoCor zunit (Carl Zeiss, Jena, Germany) equipped with a $40 x$ (NA 1.2) water immersion apochromat objective (Carl Zeiss) was used. A helium neon laser $(633 \mathrm{~nm})$ and for FCCS additionally an argon laser $(488 \mathrm{~nm})$ was used for illumination. Samples were measured in eight-well LabTekchamber slides (Nunc, Rochester, NY). If nothing else mentioned, measurements were performed in HBG $\mathrm{pH} 7.4$ at a temperature of $22.5^{\circ} \mathrm{C}$. Correlation was performed using ConfoCor 2 software. A detailed description of the various experimental setups of FCS and FCCS measurements and the theory of FCS can be found in the Supporting Information.

Cell culture. HeLa cells were grown in Dulbecco's Modified Eagle's Medium (DMEM) (1000 mg/mL glucose, L-glutamine and sodium bicarbonate) supplemented with $10 \% \mathrm{FBS}, 100 \mathrm{U} / \mathrm{mL}$ penicillin, $100 \mu \mathrm{g} / \mathrm{mL}$ streptomycin at $37^{\circ} \mathrm{C}$ and $5 \% \mathrm{CO}_{2}$ in a humidified incubator.

Cellular uptake experiments using flow cytometric analysis. Cells were seeded in 24-well plates (Corning Costar, Sigma-Aldrich, Germany) at a density of 20.000 cells/well. After $24 \mathrm{~h}$, medium was replaced with $400 \mu \mathrm{L}$ fresh medium. $0.5 \mathrm{nmol}_{6}$-CF or $\mathrm{H}_{6}$-GFP were diluted in HBG ( $\mathrm{pH} 7.4$ ), 50 g MOF NPs $(5 \mathrm{mg} / \mathrm{mL}$ in HBG, $\mathrm{pH} 7.4$ ) were added (final volume $50 \mu \mathrm{L}$ ) and the solution was strongly mixed. For the co-delivery of $\mathrm{H}_{6}$-GFP and $\mathrm{H}_{6}$ - $\mathrm{Tf}^{*}$, $0.25 \mathrm{nmol} \mathrm{H}_{6}$-GFP and $0.25 \mathrm{nmol} \mathrm{H}_{6}$-Tf* were pre-mixed in HBG ( $\mathrm{pH}_{7.4}$ ) before $50 \mu \mathrm{g} \mathrm{Zr}$-fum MOF NPs $(5 \mathrm{mg} / \mathrm{mL}$ in $\mathrm{HBG}, \mathrm{pH} 7.4$ ) were added (final volume $50 \mu \mathrm{L}$ ). The mixtures were incubated for $15 \mathrm{~min}$ at room temperature, diluted 1:2 with HBG ( $\mathrm{pH} 7.4$, final volume $100 \mu \mathrm{L})$ and added to the cells (100 $\mu \mathrm{L} \mathrm{MOF/His-tag} \mathrm{solution} \mathrm{per} \mathrm{well).}$ Controls were performed without the addition of MOF NPs. Cells were incubated for $24 \mathrm{~h}$ at $37^{\circ} \mathrm{C}$ and $5 \% \mathrm{CO}_{2}$ in a humidified incubator. In case of HKUST-1 MOF NPs, medium was changed after $2 \mathrm{~h}$ and cells were incubated for further $22 \mathrm{~h}$ in fresh medium. Cells were washed with PBS ( $\mathrm{pH} 7.4$ ), detached with trypsin/ EDTA and diluted with fresh medium. Cells were centrifuged and resuspended in $500 \mu \mathrm{L}$ PBS containing $10 \%$ FBS at $\mathrm{pH} 4$ to quench extracellular fluorescence. $500 \mathrm{ng} / \mu \mathrm{L}$ DAPI (4,6diamidino-2-phenylindole) were added shortly before the measurement. The cellular fluorescence was assayed by excitation of DAPI at $405 \mathrm{~nm}$ and detection of emission at $450 \mathrm{~nm}$, fluorescein at $488 \mathrm{~nm}$ and detection of emission at $510 \mathrm{~nm}$. For the co-delivery of $\mathrm{H}_{6}$-GFP and $\mathrm{H}_{6}$-Tf* the cellular fluorescence was also assayed by excitation of A647N at $635 \mathrm{~nm}$ and detection of emission at $665 \mathrm{~nm}$. Cells were appropriately gated by forward/ sideward scatter and pulse width for exclusion of doublets. DAPI was used to discriminate between viable and dead cells. Data were recorded by Cyan $^{\mathrm{TM}}$ ADP flow cytometer (Dako, Hamburg, Germany) using Summit ${ }^{\mathrm{TM}}$ acquisition software (Summit, Jamesville, NY). Ten thousand gated cells per sample were collected. Analysis was done by FlowJo 7.6.5 flow cytometric analysis software. All experiments were performed in triplicates. MFI was calculated by FlowJo 7.6.5 flow cytometric analysis software and is depicted as normalization to $\mathrm{HBG} \pm \mathrm{SD}(\mathrm{n}=3)$.

Confocal laser scanning microscopy. Cells were seeded in 8-Well Nunc chamber slights (Thermo Scientific, Germany) at a density of $\mathbf{1 2 . 0 0 0}$ cells/well. Wells were coated with collagen A prior to seeding. After $24 \mathrm{~h}$ medium was replaced with $240 \mu \mathrm{L}$ fresh medium. The various samples were prepared in the same way as has been described above but in a final volume of $60 \mu \mathrm{L} \mathrm{HBG}$. $30 \mu \mathrm{g}$ MOF NPs were functionalized with $0.3 \mathrm{nmol}_{6}-\mathrm{CF}$ or $\mathrm{H}_{6}$-GFP in $30 \mu \mathrm{L}$ HBG $(\mathrm{pH} 7.4)$. In case of the co-

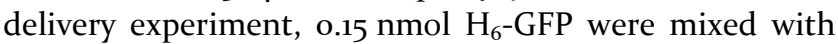
$0.15 \mathrm{nmol} \mathrm{H}_{6}$-Tf* before the addition of $30 \mu \mathrm{g} \mathrm{Zr}$-fum MOF NPs. After incubation of the mixtures for $15 \mathrm{~min}$ at room temperature, they were diluted 1:2 in HBG ( $\mathrm{pH} 7.4$, final volume $60 \mu \mathrm{L}$ ). The mixtures were added to the cells (6o $\mu \mathrm{L} \mathrm{MOF/His-tag} \mathrm{solution} \mathrm{per} \mathrm{well)} \mathrm{and} \mathrm{incubated} \mathrm{for}$ $24 \mathrm{~h}$. Controls were performed without the addition of MOF NPs. In case of HKUST-1 MOF NPs, the medium was changed after $2 \mathrm{~h}$ and cells were incubated for further $22 \mathrm{~h}$ in fresh medium. Prior to imaging nuclei were stained with Hoechst dye $(500 \mathrm{ng} / \mu \mathrm{L})$. Medium was replaced by DMEM without phenol red supplemented with $10 \%$ FBS, $100 \mathrm{U} / \mathrm{mL}$ penicillin, $100 \mu \mathrm{g} / \mathrm{mL}$ streptomycin and cells were imaged using a Leica TCS SP8 confocal microscope with an 63x DIC oil immersion objective (Plan-APOCHROMAT). For imaging of z-stacks, cells were fixated for $30 \mathrm{~min}$, using $4 \%(\mathrm{w} / \mathrm{v})$ paraformaldehyde solution followed by 3 washes with PBS ( $\mathrm{pH} 7.4)$. The nucleus was stained with DAPI (50o ng/ $\mu \mathrm{L})$, and Actin with rhoadmine-phalloidin $(2 \mu \mathrm{L} / \mathrm{mL})$ for $15 \mathrm{~min}$ at room temperature. Staining solution was replaced with 
PBS ( $\mathrm{pH} 7.4)$ and cells were stored at $4{ }^{\circ} \mathrm{C}$. Images were recorded with a $\mathrm{z}$-distance of $0.3 \mu \mathrm{m}$ from basolateral (top) to apical (bottom) pole of a representative cell. Pictures were taken at $405 \mathrm{~nm}$ (Hoechst dye or DAPI), $488 \mathrm{~nm} \quad\left(\mathrm{H}_{6}-\mathrm{GFP}\right.$ or $\left.\mathrm{H}_{6}-\mathrm{CF}\right), \quad 514 \mathrm{~nm}$ (rhodaminephalloidine), $633 \mathrm{~nm}$ (Atto647N).

Endocytosis inhibitory assay. HeLa cells were seeded in 24-Well plates (Corning Costar, Sigma-Aldrich, Germany) at a density of 50.000 cells/well. After $24 \mathrm{~h}$, medium was replaced with $400 \mu \mathrm{L}$ fresh medium containing the different endocytosis inhibitors, chlorpromazine (final concentration $5 \mu \mathrm{M}, 10 \mu \mathrm{M}, 20 \mu \mathrm{M}$ ), amiloride (final concentration $1 \mathrm{mM}, 2 \mathrm{mM}, 5 \mathrm{mM}$ ) and genistein (final concentration $100 \mu \mathrm{M}, 150 \mu \mathrm{M}, 200 \mu \mathrm{M})$. Cells were preincubated with the different inhibitors or at $4{ }^{\circ} \mathrm{C}$ for 30 min before addition of the $\mathrm{H}_{6}$-GFP/Zr-fum MOF NPs. $0.5 \mathrm{nmol} \mathrm{H}_{6}$-GFP were diluted in HBG ( $\left.\mathrm{pH} 7.4\right)$, $50 \mu \mathrm{g} \mathrm{Zr-}$ fum MOF NPs $(5 \mathrm{mg} / \mathrm{mL}$ in $\mathrm{HBG}, \mathrm{pH} 7.4)$ were added (final volume $50 \mu \mathrm{L}$ ) and the solution was strongly mixed. The mixture was incubated for $15 \mathrm{~min}$ at room temperature, diluted 1:2 with HBG ( $\mathrm{pH} 7.4$, final volume $100 \mu \mathrm{L})$ and added to the cells $\left(100 \mu \mathrm{L} \mathrm{Zr}-\right.$ fum $/ \mathrm{H}_{6}-\mathrm{GFP}$ solution per well). Cells were incubated for $2 \mathrm{~h}$ at $37^{\circ} \mathrm{C}$ and $5 \%$ $\mathrm{CO}_{2}$ or at $4{ }^{\circ} \mathrm{C}$. Cells were washed with PBS ( $\mathrm{pH} 7.4$ ), detached with trypsin/EDTA and diluted with fresh medium. Cells were centrifuged and resuspended in $500 \mu \mathrm{L}$ PBS containing $10 \% \mathrm{FBS}$ at $\mathrm{pH} 4$ to quench extracellular fluorescence. $500 \mathrm{ng} / \mu \mathrm{L}$ DAPI (4,6-diamidino-2phenylindole) were added shortly before the measurement. The cellular fluorescence was assayed by excitation of DAPI at $405 \mathrm{~nm}$ and detection of emission at $450 \mathrm{~nm}$ and fluorescein at $488 \mathrm{~nm}$ and detection of emission at $510 \mathrm{~nm}$. Cells were appropriately gated by forward/ sideward scatter and pulse width for exclusion of doublets. DAPI was used to discriminate between viable and dead cells. Data were recorded by Cyan ${ }^{\mathrm{TM}}$ ADP flow cytometer (Dako, Hamburg, Germany) using Summit ${ }^{\text {TM }}$ acquisition software (Summit, Jamesville, NY). Five thousand gated cells per sample were collected. Analysis was done by FlowJo 7.6.5 flow cytometric analysis software. Data is presented as \% cellular uptake, of cellular uptake of $\mathrm{Zr}$ fum $/ \mathrm{H}_{6}$-GFP NPs at $37{ }^{\circ} \mathrm{C} \pm \mathrm{SD}(\mathrm{n}=3)$.

Delivery of pro-apoptopic peptides and CytC. Cells were seeded in 96-Well plates (Corning Costar, SigmaAldrich, Germany) at a density of 4.000 cells/well. After $24 \mathrm{~h}$, medium was replaced with $80 \mu \mathrm{L}$ fresh medium. $1 \mathrm{nmol}$ of $\mathrm{H}_{6}$-Bak, $\mathrm{H}_{6}$-Bad, $\mathrm{H}_{6}$-KLK or $\mathrm{H}_{6}$-CytC was diluted in HBG ( $\mathrm{pH} 7.4$ ), $20 \mu \mathrm{g} \mathrm{Zr}$-fum MOF NPs $(5 \mathrm{mg} / \mathrm{mL}$ in HBG $\mathrm{pH}$ 7.4) were added followed by strongly mixing of the samples (final volume $10 \mu \mathrm{L}$ ). Controls were performed without the addition of Zr-fum MOF NPs. The mixtures were incubate for $15 \mathrm{~min}$ at room temperature, diluted 1:2 with HBG ( $\mathrm{pH} 7.4$, final volume $20 \mu \mathrm{L}$ ), added to the cells ( $20 \mu \mathrm{L} \mathrm{Zr-fum/His-tag} \mathrm{solution} \mathrm{per} \mathrm{well)} \mathrm{and}$ incubated for $48 \mathrm{~h}$. Analysis of cytotoxicity was carried out by MTT assay, as is described in the following.

Cell viability assay. Cells were seeded in 96-well plates (Corning Costar, Sigma-Aldrich, Germany) at a density of 4000 cells/well. After $24 \mathrm{~h}$ medium was replaced with $80 \mu \mathrm{L}$ fresh medium. The appropriate amount of com- pound to be tested was diluted in $\mathrm{HBG}(\mathrm{pH} 7.4$ ) and $20 \mu \mathrm{L}$ of each sample/well were added. Cells were incubated for $48 \mathrm{~h}$ at $37^{\circ} \mathrm{C}$ and $5 \% \mathrm{CO}_{2}$ in a humified incubator. $10 \mu \mathrm{L}$ of MTT (3-(4,5-dimethylthia-zol-2-yl)-2,5diphenyltetrazolium bromide) $(5 \mathrm{mg} / \mathrm{mL})$ were added to each well reaching a final concentration of $0.5 \mathrm{mg} / \mathrm{mL}$. After an incubation time of $\mathbf{2} \mathrm{h}$, unreacted dye and medium were removed and the 96-well plates were frozen at $-80{ }^{\circ} \mathrm{C}$ for at least $30 \mathrm{~min}$. To dissolve the purple formazan product $100 \mu \mathrm{L}$ DMSO were added per well and the plate was incubated for $30 \mathrm{~min}$ at $37{ }^{\circ} \mathrm{C}$ with shaking. The wells were quantified by measuring absorbance at $590 \mathrm{~nm}$ with background correction at $630 \mathrm{~nm}$ using a microplate reader (TecanSpectrafluor Plus, Tecan, Switzerland). All studies were performed in triplicates. The relative cell viability (\%) related to control wells treated only with 20 $\mu \mathrm{L} \mathrm{HBG}(\mathrm{pH} 7.4)$ was calculated as ([A] test/[A] control) $\times$ $100 \%$.

Statistical analysis. The statistical significance of experiments were analyzed using the t-test, $* * * * \mathrm{p} \leq 0.0001$, *** $\mathrm{p} \leq 0.001,{ }^{* *} \mathrm{p} \leq 0.01,{ }^{*} \mathrm{p} \leq 0.05$.

\section{ASSOCIATED CONTENT}

Supporting Information. Additional Materials and Methods, synthesis and analysis of peptides and His-tagged functional units, characterization of MOF NPs, Supplementary Figures. This material is available free of charge via the Internet at http://pubs.acs.org.

\section{AUTHOR INFORMATION}

\section{Corresponding Author}

*ulrich.laechelt@cup.uni-muenchen.de, stefan.wuttke@cup.lmu.de

\section{Author Contributions}

The manuscript was written through contributions of all authors. All authors have given approval to the final version of the manuscript.

\section{ACKNOWLEDGMENT}

We are grateful for financial support from the Excellence Cluster Nanosystems Initiative Munich (NIM) and the Center for NanoScience Munich (CeNS). Funding through the DFG SFB 1032 and DFG project WU 622/4-1 is greatly appreciated. We thank Olga Brück and Wofgang Rödl for technical assistance and appreciate the help of cameraman Michael Beetz.

\section{ABBREVIATIONS}

A647N, ATTO647N; Acr, acridine; CF, carboxyfluorescein; CLSM, confocal laser scanning microscopy; CUS, coordinatively unsaturated metal sites; CytC, cytochrome C; DLS, dynamic light scattering; FCS, fluorescence correlation spectroscopy; FCCS, fluorescence cross-correlation spectroscopy; GFP, green fluorescent protein; HBG, HEPES buffered glucose; MFI, mean fluorescence intensity; MOF, metal-organic framework; NP, nanoparticle; SEM, scanning electron microscopy; SAMCOPs, self-assembling multifunctional nanoparticles; TGA, thermogravimetric analysis; Tf, transferrin; XRD, X-ray diffraction 


\section{REFERENCES}

(1) Goesmann, H.; Feldmann, C. Angew Chem Int Ed Engl 2010, 49, 1362.

(2) Tibbitt, M. W.; Dahlman, J. E.; Langer, R. J Am Chem Soc 2016, 138, 704.

(3) Calandra, P.; Caschera, D.; Turco Liveri, V.; Lombardo, D. Colloids and Surfaces A: Physicochemical and Engineering Aspects 2015, 484, 164.

(4) Torchilin, V. P. Pharm Res 2007, 24, 1.

(5) Nishiyama, N.; Matsumura, Y.; Kataoka, K. Cancer Sci 2016, 107, 867.

(6) Discher, B. M.; Won, Y. Y.; Ege, D. S.; Lee, J. C.; Bates, F. S.; Discher, D. E.; Hammer, D. A. Science 1999, 284, 1143.

(7) Davis, M. E. Mol Pharm 2oog, 6, 659.

(8) Park, I. K.; von Recum, H. A.; Jiang, S.; Pun, S. H. Langmuir 2006, 22, 8478.

(9) Sanvicens, N.; Marco, M. P. Trends Biotechnol 2oo8, 26, 425 .

(10) Jia, F.; Liu, X.; Li, L.; Mallapragada, S.; Narasimhan, B.; Wang, Q. J Control Release 2013, 172, 1020.

(11) Torchilin, V. P. Annu.Rev.Biomed Eng 2006, 8, 343

(12) Fu, A.; Tang, R.; Hardie, J.; Farkas, M. E.; Rotello, V. M. Bioconjug Chem 2014, 25, 1602.

(13) Furukawa, H.; Cordova, K. E.; O'Keeffe, M.; Yaghi, O. M. Science 2013, 341, 1230444.

(14) Zhou, H. C.; Long, J. R.; Yaghi, O. M. Chem Rev 2012, 112,673 .

(15) Zhou, H. C.; Kitagawa, S. Chem Soc Rev 2014 43, 5415 .

(16) Horcajada, P.; Chalati, T.; Serre, C.; Gillet, B.; Sebrie, C.; Baati, T.; Eubank, J. F.; Heurtaux, D.; Clayette, P.; Kreuz, C.; Chang, J. S.; Hwang, Y. K.; Marsaud, V.; Bories, P. N.; Cynober, L.; Gil, S.; Ferey, G.; Couvreur, P.; Gref, R. Nat Mater 2010, 9, 172.

(17) Baati, T.; Horcajada, P.; Gref, R.; Couvreur, P.; Serre, C. J Pharm Biomed Anal 2011, 56, 758.

(18) Wuttke, S.; Zimpel, A.; Bein, T.; Braig, S.; Stoiber, K.; Vollmar, A.; Muller, D.; Haastert-Talini, K.; Schaeske, J.; Stiesch, M.; Zahn, G.; Mohmeyer, A.; Behrens, P.; Eickelberg, O.; Bolukbas, D. A.; Meiners, S. Adv Healthc Mater 2016, DOI: 10.1002/adhm.201600818 [Epub ahead of print]

(19) Taylor-Pashow, K. M.; Della Rocca, J.; Xie, Z.; Tran, S.; Lin, W. J Am Chem Soc 2009, 131, 14261.

(20) Zheng, H.; Zhang, Y.; Liu, L.; Wan, W.; Guo, P.; Nystrom, A. M.; Zou, X. J Am Chem Soc 2016, 138, 962.

(21) Yang, Y.; Hu, Q.; Zhang, Q.; Jiang, K.; Lin, W.; Yang, Y.; Cui, Y.; Qian, G. Mol Pharm 2016, 13, 2782.

(22) Wuttke, S.; Braig, S.; Preiss, T.; Zimpel, A.; Sicklinger, J.; Bellomo, C.; Radler, J. O.; Vollmar, A. M.; Bein, T. Chem Commun (Camb) 2015, 51, 15752.

(23) He, C.; Lu, K.; Liu, D.; Lin, W. J Am Chem Soc 2014, 136, 5181.

(24) Tan, L.-L.; Li, H.; Qiu, Y.-C.; Chen, D.-X.; Wang, X.; Pan, R.-Y.; Wang, Y.; Zhang, S. X.-A.; Wang, B.; Yang, Y.-W. Chem Sci 2015, 6, 1640.

(25) Wang, X. G.; Dong, Z. Y.; Cheng, H.; Wan, S. S.; Chen, W. H.; Zou, M. Z.; Huo, J. W.; Deng, H. X.; Zhang, X. Z. Nanoscale 2015, 7, 16061.

(26) Levine, D. J.; Runcevski, T.; Kapelewski, M. T.; Keitz, B. K.; Oktawiec, J.; Reed, D. A.; Mason, J. A.; Jiang, H. Z.; Colwell, K. A.; Legendre, C. M.; FitzGerald, S. A.; Long, J. R. J Am Chem Soc 2016, 138, 10143 .

(27) Zhuang, J.; Kuo, C. H.; Chou, L. Y.; Liu, D. Y.; Weerapana, E.; Tsung, C. K. ACS nano 2014, 8, 2812.

(28) Wuttke, S.; Lismont, M.; Escudero, A.; Rungtaweevoranit, B.; Parak, W. J. Biomaterials 2017, accepted.
(29) Liang, K.; Ricco, R.; Doherty, C. M.; Styles, M. J.; Bell S.; Kirby, N.; Mudie, S.; Haylock, D.; Hill, A. J.; Doonan, C. J.; Falcaro, P. Nature communications 2015, 6, 7240.

(30) Liang, K.; Coghlan, C. J.; Bell, S. G.; Doonan, C.; Falcaro, P. Chem Commun (Camb) 2016, 52, 473.

(31) Lu, K.; He, C.; Lin, W. J Am Chem Soc 2015, 137, 76oo.

(32) Park, J.; Feng, D.; Yuan, S.; Zhou, H. C. Angew Chem Int Ed Engl 2015, 54, 430 .

(33) Liu, J.; Yang, Y.; Zhu, W.; Yi, X.; Dong, Z.; Xu, X.; Chen, M.; Yang, K.; Lu, G.; Jiang, L.; Liu, Z. Biomaterials 2016, 97, 1.

(34) Lismont, M.; Dreesen, L.; Wuttke, S. Adv Funct Mater 2017, accepted.

(35) Horcajada, P.; Gref, R.; Baati, T.; Allan, P. K.; Maurin, G.; Couvreur, P.; Ferey, G.; Morris, R. E.; Serre, C. Chem Rev 2012, $112,1232$.

(36) Rungtaweevoranit, B.; Zhao, Y.; Min Choi, K.; Yaghi, O. M. Nano Research 2016, 9, 47.

(37) Furukawa, S.; Reboul, J.; Diring, S.; Sumida, K.; Kitagawa, S. Chem Soc Rev 2014, 43, 5700.

(38) He, C.; Liu, D.; Lin, W. Chem Rev 2015, 115, 11079.

(39) Zimpel, A.; Preiß, T.; Röder, R.; Engelke, H.; Ingrisch, M.; Peller, M.; Rädler, J. O.; Wagner, E.; Bein, T.; Lächelt, U.; Wuttke, S. Chemistry of Materials 2016, 28, 3318.

(40) McGuire, C. V.; Forgan, R. S. Chemical Communications 2015, 51, 5199.

(41) Block, H.; Maertens, B.; Spriestersbach, A.; Brinker, N.; Kubicek, J.; Fabis, R.; Labahn, J.; Schafer, F. Methods Enzymol 2009, 463, 439 .

(42) Hochuli, E.; Bannwarth, W.; Döbeli, H.; Gentz, R.; D, S Nat Biotechnol 1988, 6, 1321

(43) June, R. K.; Gogoi, K.; Eguchi, A.; Cui, X. S.; Dowdy, S. F. J Am Chem Soc 2010, 132, 1068 o.

(44) Wieneke, R.; Laboria, N.; Rajan, M.; Kollmannsperger, A.; Natale, F.; Cardoso, M. C.; Tampe, R. J Am Chem Soc 2014, 136, 13975.

(45) Postupalenko, V.; Desplancq, D.; Orlov, I.; Arntz, Y.; Spehner, D.; Mely, Y.; Klaholz, B. P.; Schultz, P.; Weiss, E.; Zuber, G. Angew Chem Int Ed Engl 2015, 54, 10583.

(46) Chiu, H. Y.; Deng, W.; Engelke, H.; Helma, J.; Leonhardt, H.; Bein, T. Sci Rep 2016, 6, 25019.

(47) Huo, J.; Brightwell, M.; El Hankari, S.; Garai, A.; Bradshaw, D. J Mater Chem 2013, 1, 15220.

(48) Wißmann, G.; Schaate, A.; Lilienthal, S.; Bremer, I.; Schneider, A. M.; Behrens, P. Microporous Mesoporous Mater 2012, 152, 64 .

(49) Zahn, G.; Schulze, H. A.; Lippke, J.; König, S.; Sazama, U.; Fröba, M.; Behrens, P. Microporous Mesoporous Mater 2015, 203, 186.

(50) Ueda, E. K.; Gout, P. W.; Morganti, L. Journal of chromatography. A 2003, 988, 1.

(51) Gaberc-Porekar, V.; Menart, V. Journal of biochemical and biophysical methods 2001, 49, 335.

(52) Chalati, T.; Horcajada, P.; Gref, R.; Couvreur, P.; Serre, C. J Mater Chem 2011, 21, 2220.

(53) Baati, T.; Njim, L.; Neffati, F.; Kerkeni, A.; Bouttemi, M.; Gref, R.; Najjar, M.; Zakhama, A.; Couvreur, P.; Serre, C.; Horcajada, P. Chem Sci 2013, 4, 1597.

(54) Li, K.-Y. A.; Chang, H.-A.; Hsu, C.-J. RCS Advances 2015, 5, 32520.

(55) McKinlay, A. C.; Eubank, J. F.; Wuttke, S.; Xiao, B.; Wheatley, P. S.; Bazin, P.; Lavalley, J.-C.; Daturi, M.; Vimont, A.; De Weireld, G.; Horcajada, P.; Serre, C.; Morris, R. E. Chemistry of Materials 2013, 25, 1592.

(56) Hirschle, P.; Prei; Auras, F.; Pick, A.; Volkner, J.; Valdeperez, D.; Witte, G.; Parak, W. J.; Radler, J. O.; Wuttke, S. CrystEngComm 2016, 18, 4359. 
(57) Tay, C. Y.; Setyawati, M. I.; Xie, J.; Parak, W. J.; Leong, D. T. Adv Funct Mater 2014, 24, 5936.

(58) Martin, R.; Edsall, J. J Am Chem Soc 196o, 82, 1107.

(59) Dietl, C.; Hintz, H.; Ruhle, B.; Schmedt Auf der Gunne, J.; Langhals, H.; Wuttke, S. Chemistry 2015, 21, 10714.

(6o) Wuttke, S.; Dietl, C.; Hinterholzinger, F. M.; Hintz, H.; Langhals, H.; Bein, T. Chem Commun (Camb) 2014, 50, 3599.

(61) Orellana-Tavra, C.; Mercado, S. A.; Fairen-Jimenez, D. Adv Healthc Mater 2016, 5, 2261.

(62) Li, R.; Boehm, A. L.; Miranda, M. B.; Shangary, S.; Grandis, J. R.; Johnson, D. E. Neoplasia 2007, 9, 801.

(63) Javadpour, M. M.; Juban, M. M.; Lo, W. C.; Bishop, S. M.; Alberty, J. B.; Cowell, S. M.; Becker, C. L.; McLaughlin, M. L. J Med Chem 1996, 39, 3107.

(64) Ellerby, H. M.; Arap, W.; Ellerby, L. M.; Kain, R.; Andrusiak, R.; Rio, G. D.; Krajewski, S.; Lombardo, C. R.; Rao, R.; Ruoslahti, E.; Bredesen, D. E.; Pasqualini, R. Nat Med 1999, 5, 1032.
(65) Bratton, S. B.; Salvesen, G. S. J Cell Sci 2010, 123, 3209.

(66) Kim, S. K.; Foote, M. B.; Huang, L. Biomaterials 2012, 33, 3959 .

(67) Zhang, J.; Wu, L.; Meng, F.; Wang, Z.; Deng, C.; Liu, H.; Zhong, Z. Langmuir 2012, 28, 2056.

(68) Ng, D. Y.; Fahrer, J.; Wu, Y.; Eisele, K.; Kuan, S. L.; Barth, H.; Weil, T. Adv Healthc Mater 2013, 2, 1620.

(69) Mendez, J.; Morales Cruz, M.; Delgado, Y.; Figueroa, C. M.; Orellano, E. A.; Morales, M.; Monteagudo, A.; Griebenow, K. Mol Pharm 2014, 11, 102.

(70) Schwille, P.; Meyer-Almes, F. J.; Rigler, R. Biophys J 1997, 72, 1878.

(71) Rigler, R.; Földes-Papp, Z.; Meyer-Almes, F. J.; C., S.; M., V.; A., S. J Biotechnol 1998, 63, 97. 
Insert Table of Contents artwork here

1

2

3

4

5

6

7

10

11

12

13

14

15

16

17

18

19

20

21

22

23

24

25

26

27

28

29

30

31

32

33

34

35

36

37

38

39

40

41

42

43

44

45

46

47

48

49

50

51

52

53

54

55

56

57

58

59

60

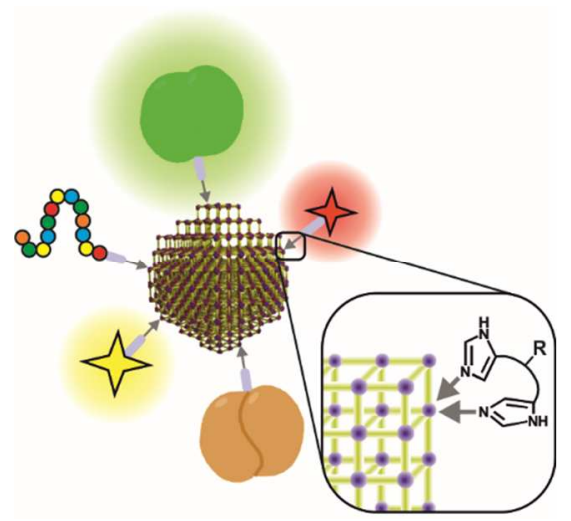


a)

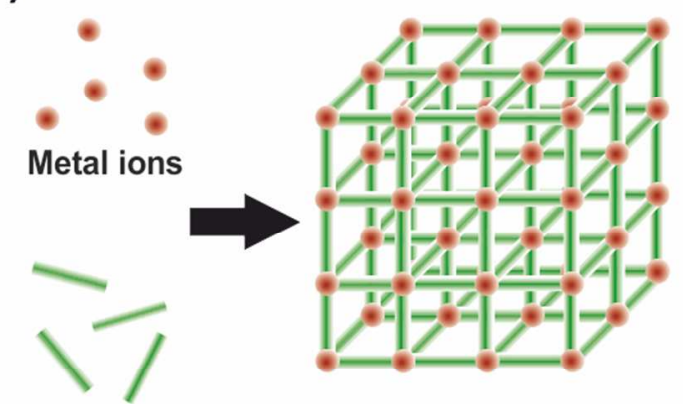

Organic linkers
Metal-organic framework (MOF) b)

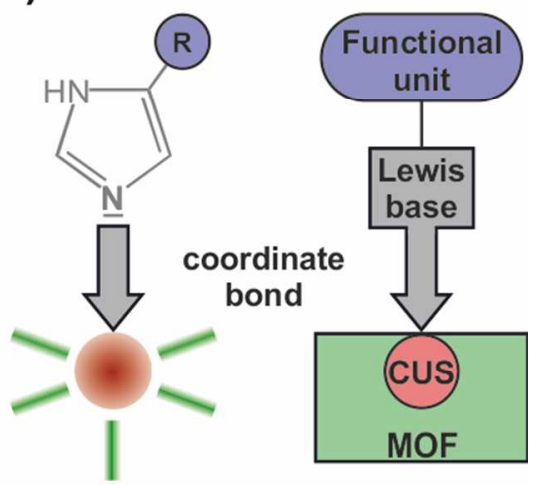

c)

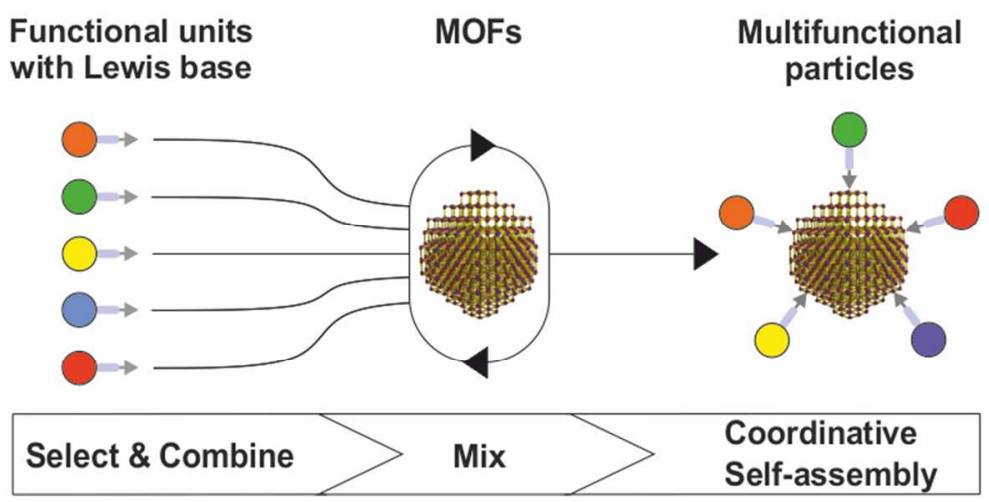

Figure 1. Illustration of coordinative self-assembly of His-tagged molecules with MOF NPs: a) molecular composition of MOFs; b) coordinative bond between the imidazole group of histidines acting as Lewis base and coordinatively unsaturated metal sites (CUS) acting as Lewis acid; c) multi-functional MOF NPs generated by coordinative attachment of different functional units via self-assembly.

$86 \times 71 \mathrm{~mm}(300 \times 300 \mathrm{DPI})$ 
a)

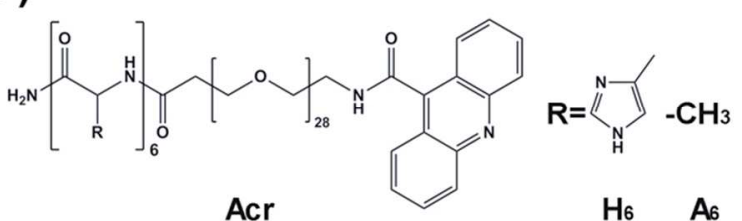

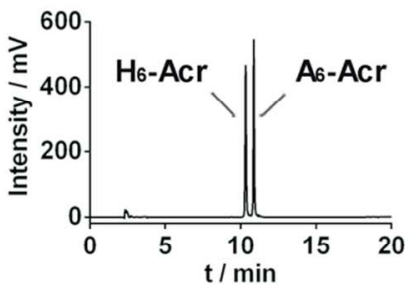

b)
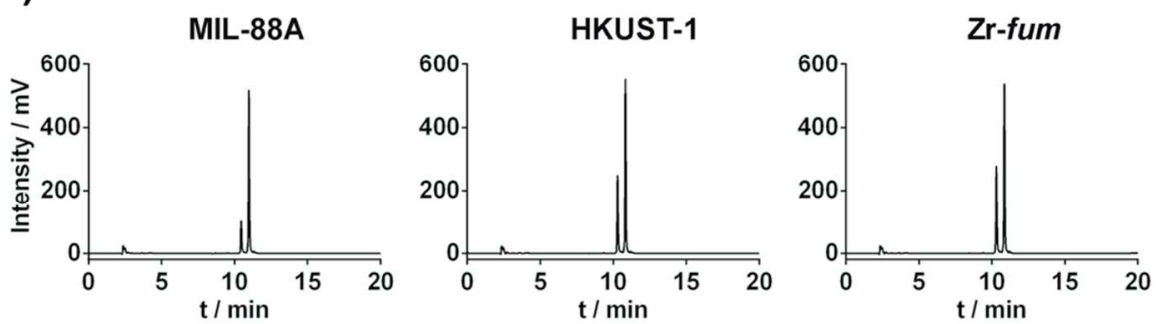

c)
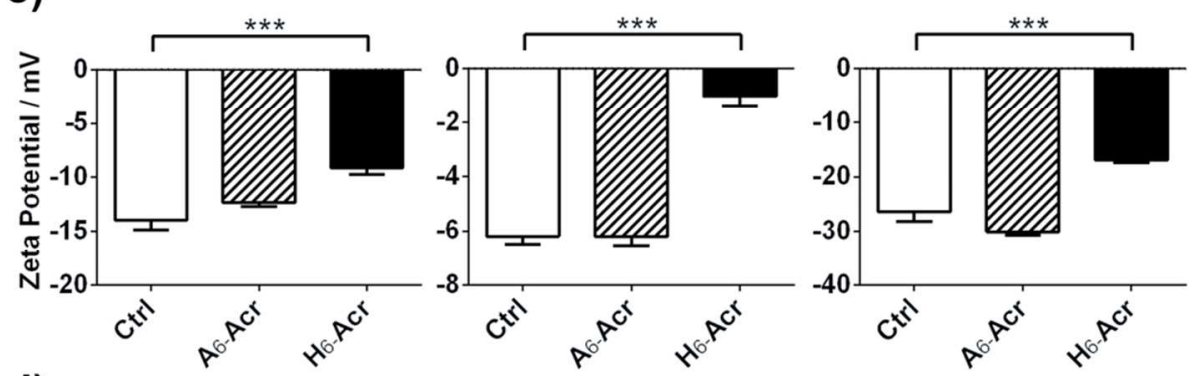

d)
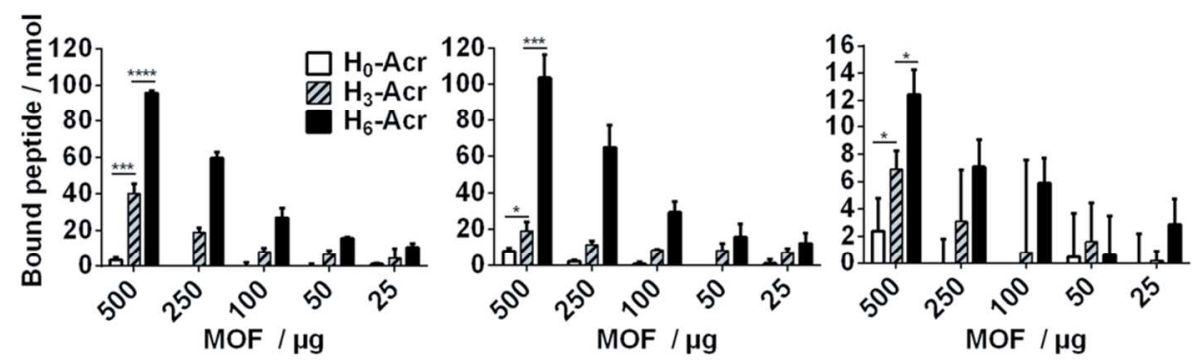

Figure 2. Acridine (Acr) peptide binding to MIL-88A (left), HKUST-1 (middle) and Zr-fum (right) particles in HEPES buffered glucose (HBG) at pH 7.4. a) Chemical structure and control chromatogram of model compounds H6-Acr, A6-Acr. b) Peptide binding (H6 vs. A6) by detection of reduced free peptides in the supernatant (RP-HPLC, $\lambda=360 \mathrm{~nm}$ ). c) Effect of peptide binding on zeta potential. d) Quantitative determination of bound peptides HO (white), H3 (pattern), H6 (black) as difference to photometrically quantified free pep-tides in the supernatant $(\lambda=360 \mathrm{~nm})$ using a UV-photometer. Please note that the scaling of $y$-axes is accommodated to the different binding capacities: $0-120 \mathrm{nmol}$ peptide in case of MIL88A and HKUST-1, 0-16 nmol peptide in case of Zr-fum.

$85 \times 111 \mathrm{~mm}(300 \times 300 \mathrm{DPI})$ 
a)
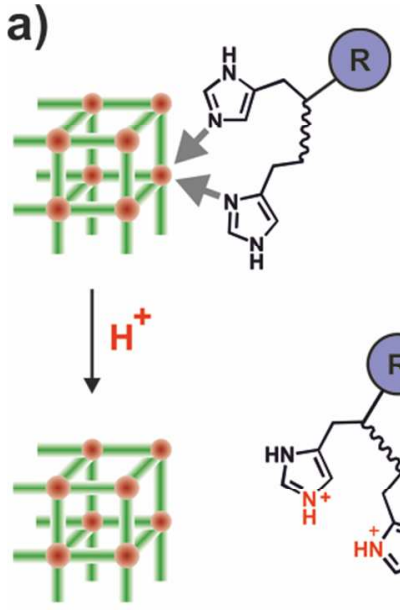

b)

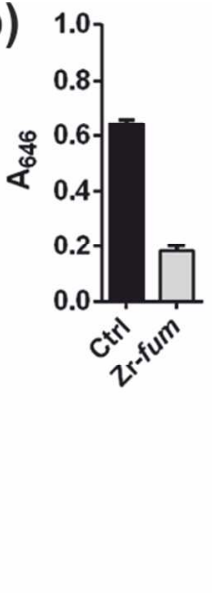

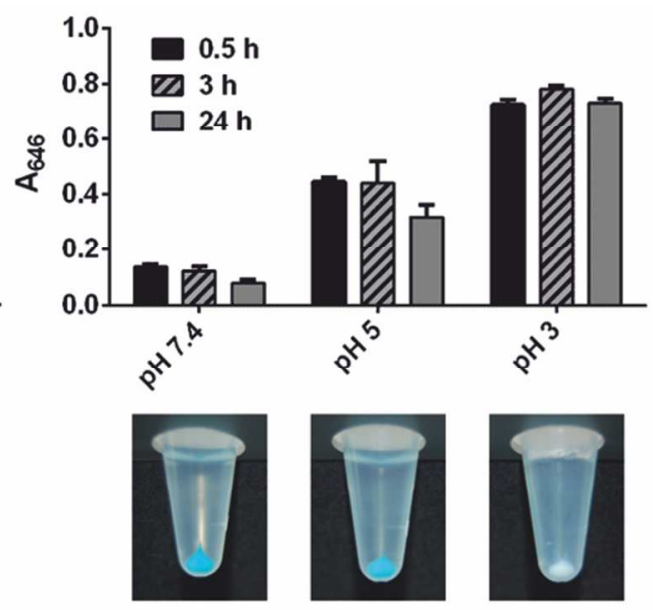

Figure 3. $\mathrm{pH}$ dependent stability of H6-tag binding to Zr-fum NPs. a) Schematic illustration of acidic detachment due to histidine protonation. b) Experimental data obtained by photometric determination $(\lambda=646 \mathrm{~nm})$ of free H6-A647N in the supernatant after centrifugation. Left: Zr-fum NPs were loaded with H6-A647N at pH 7.4 for 15 min, centrifuged and the supernatant was analyzed; Ctrl illustrates absorbance of free peptide in a sample without MOF NPs. Right: MOF NP suspensions were acidified to a defined pH and incubated for indicated times before centrifugation and analysis of the supernatant. Reaction tubes below show the MOF pellets of the same samples after $24 \mathrm{~h}$ at pH 7.4 (left), pH 5 (middle), pH 3 (right) and centrifugation; decoloration of the pellet due to acidic $\mathrm{H} 6-\mathrm{A} 647 \mathrm{~N}$ detachment at $\mathrm{pH} 3$ can be observed. 

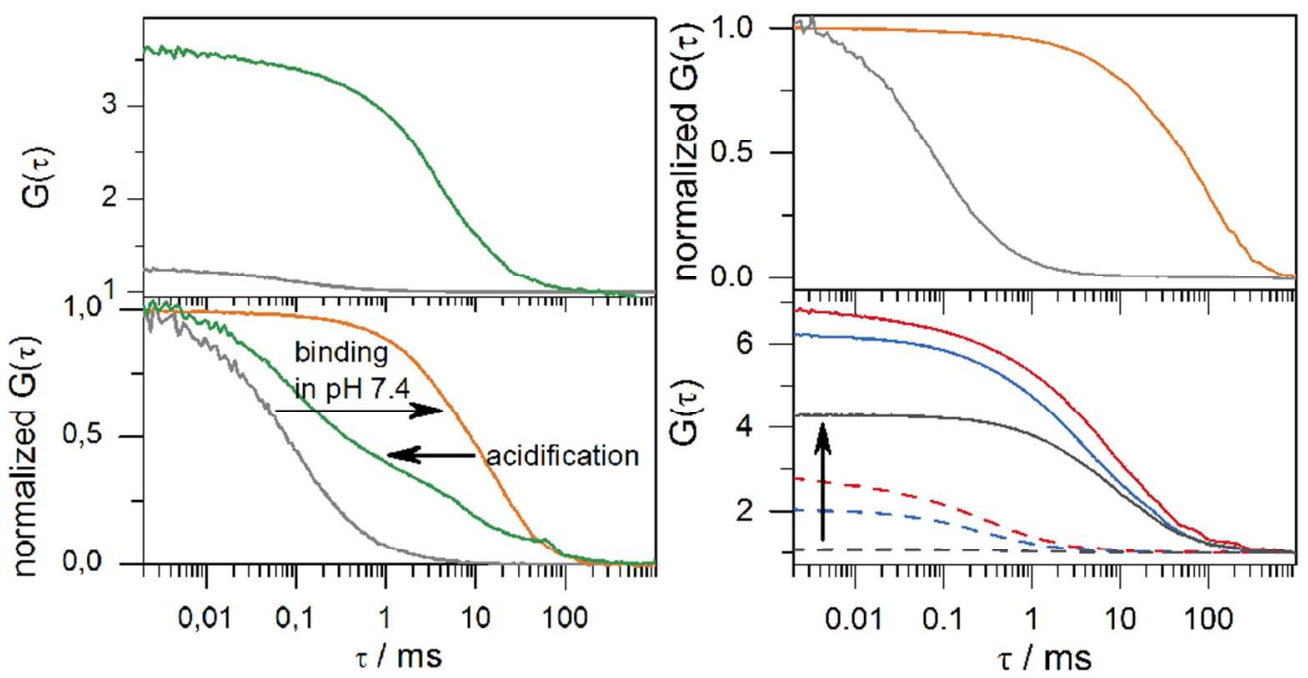

Figure 4. Investigation of Zr-fum/H6-A647N interaction by fluorescence correlation spectroscopy (FCS). Upper left: FCS time correlation functions of H6-A647N before (grey) and after Zr-fum NP addition (green). Lower left: Normalized time correlation functions of binding of $\mathrm{H6}-\mathrm{A} 647 \mathrm{~N}$ at $\mathrm{pH} 7.4$ (orange) and release upon acidification (green); free H6-A647N (grey). Upper right: Normalized time correlation functions of measurements in DMEM (10 \% FBS) of free H6-A647N (grey) and Zr-fum/H6-A647N (orange). Lower right: fluorescence cross correlation spectroscopy (FCCS) measurements of H6-GFP (blue) and H6-Tf* (red) in HBG pH 7.4 before (dotted) and after (solid) Zr-fum addition. Cross correlation before (dotted grey) and after (solid grey) Zr-fum addition.

$84 \times 44 \mathrm{~mm}(300 \times 300$ DPI $)$ 

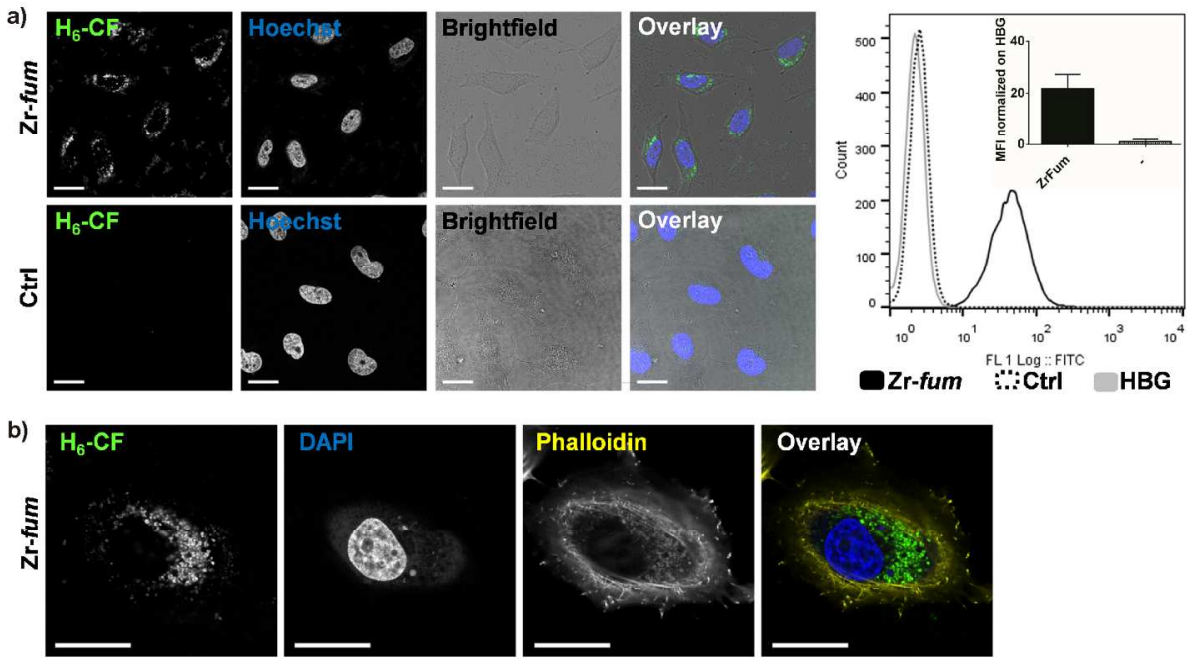

Figure 5. Cellular uptake of fluorescent peptide H6-CF mediated by Zr-fum NPs. H6-CF was incubated with Zr-fum MOF NPs for 15 min at room temperature in HBG for prefunctionalization by coordinative selfassembly. The functionalized particles were incubated with HeLa cells for $24 \mathrm{~h}$ at a concentration of 0.1 $\mathrm{mg} / \mathrm{mL} \mathrm{Zr}$-fum corresponding to $1 \mu \mathrm{M} \mathrm{H} 6-\mathrm{CF}$. Solutions containing H6-CF at same concentration but no $\mathrm{Zr}$ fum NPs served as control (Ctrl). a) Confocal laser scanning microscopy (CLSM, left) and flow cytometry (right) after incubation of HeLa cells with functional NPs Zr-fum/H6-CF (Zr-fum, CLSM upper row, flow cytometry solid black), H6-CF control without Zr-fum NPs (Ctrl, CLSM lower row, flow cytometry dotted black) or HBG (flow cytometry grey). Mean fluorescence intensity (MFI) was normalized to HBG and is depicted in the inset. CLSM left to right: green fluorescence of H6-CF, nuclear staining with Hoechst dye, brightfield image, overlay of all three channels. b) Enlarged CLSM image of a fixated HeLa cell after incubation with Zr-fum/H6-CF. Left to right: green fluorescence of $\mathrm{H6}-\mathrm{CF}$, nuclear staining with DAPI dye, actin staining with rhodamine-phalloidin, overlay of all three channels. Scale bar: $25 \mu \mathrm{m}$. Additional images can be found in the Supporting Information Figure S23 and S24. 

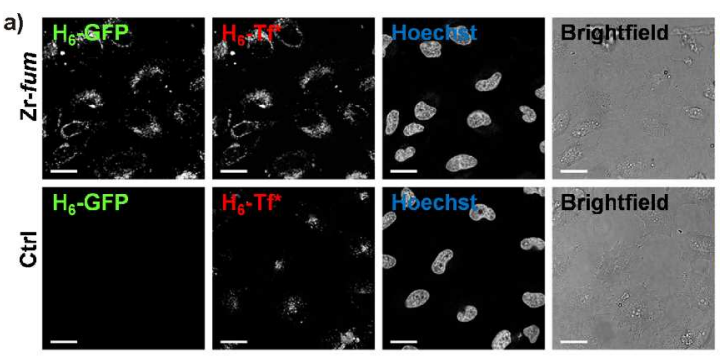

b) $\mathrm{H}_{6}$-GFP
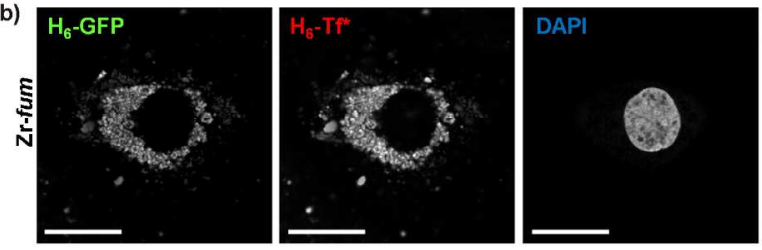
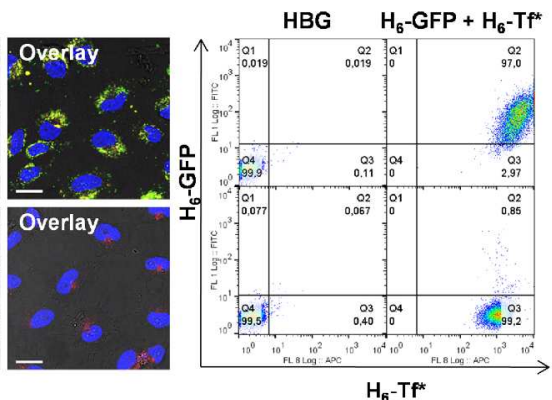

Figure 6. Simultaneous cellular uptake of fluorescent proteins H6-GFP and H6-Tf* mediated by Zr-fum NPs. An equimolar mixture of H6-GFP and H6-Tf* was incubated with Zr-fum MOF NPs for 15 min at room temperature in HBG for prefunctionalization by coordinative self-assembly. The double functionalized particles were incubated with HeLa cells for $24 \mathrm{~h}$ at a concentration of $0.1 \mathrm{mg} / \mathrm{mL} \mathrm{Zr-fum} \mathrm{corresponding} \mathrm{to}$ 0.5 HM H6-GFP and H6-Tf*. Solutions containing H6-GFP and H6-Tf* at same concentration but no $\mathrm{Zr}$-fum NPs served as control (Ctrl). a) Cellular uptake of Zr-fum/H6-GFP+H6-Tf* (upper row) or control without MOF NPs (lower row). CLSM left to right: green fluorescence of H6-GFP, red fluorescence of H6-Tf*, nuclear staining with Hoechst dye, brightfield picture, overlay of all four channels, yellow color indicates colocalization of H6-GFP and H6-Tf*. Flow cytometry analysis: HBG (left) or H6-GFP +H6-Tf* (right) with Zrfum MOF NPs (upper row) or Ctrl without MOF NPs (lower row). b) Enlarged CLSM image of a fixated HeLa cell after incubation with Zr-fum/H6-GFP+H6-Tf*. Left to right: green fluorescence of H6-GFP, red fluorescence of H6-Tf*, nuclear staining with DAPI dye, actin staining with rhodamine-phalloidin, overlay of all four channels. Scale bar: $25 \mu \mathrm{m}$. Additional images can be found in the Supporting Information Figure S27 and S28 and a 3D reconstruction movie of a cell treated with Zr-fum/H6-GFP is provided as supporting material for download.

$177 \times 89 \mathrm{~mm}(300 \times 300 \mathrm{DPI})$ 


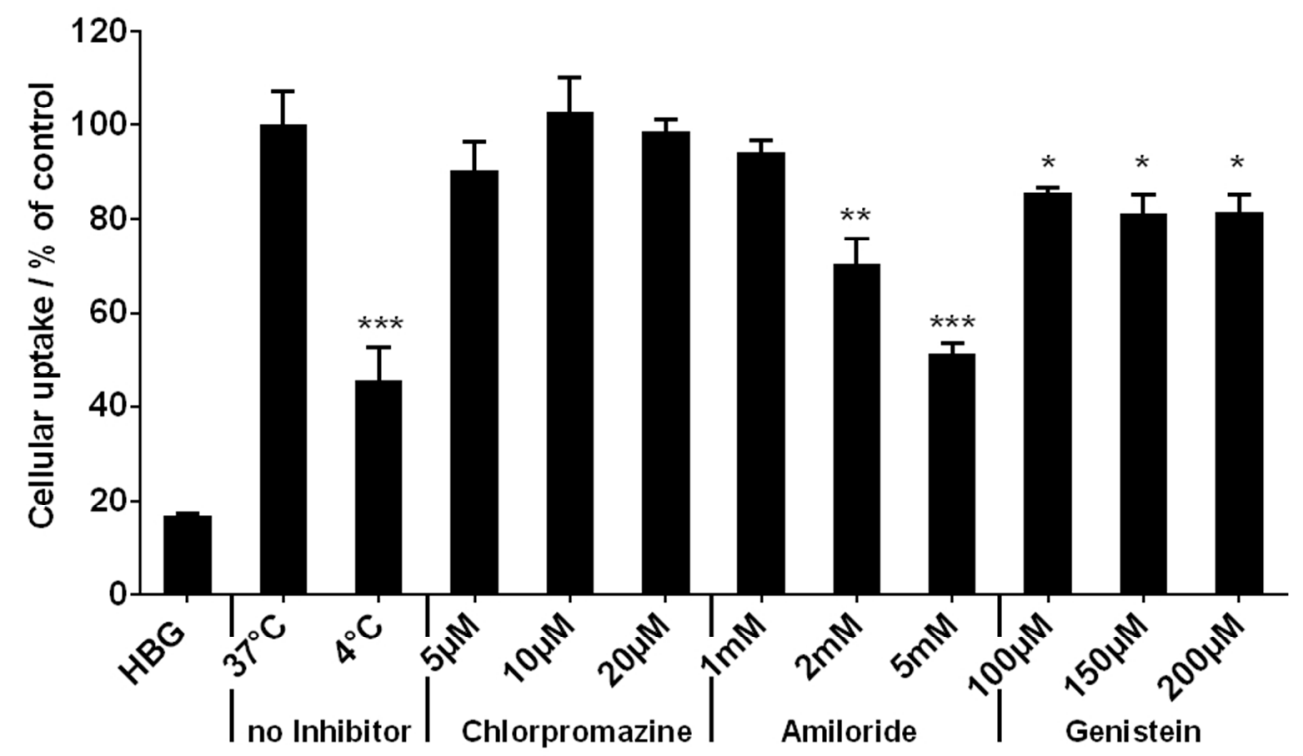

Figure 7. Evaluation of endocytosis inhibition of Zr-fum/H6-GFP nanoparticles. Pre-Incubation of HeLa cells with different inhibitors or at $4^{\circ} \mathrm{C}$ for $30 \mathrm{~min}$, followed by incubation with Zr-fum/H6-GFP for $2 \mathrm{~h}$ at $37^{\circ} \mathrm{C}$ or $4{ }^{\circ} \mathrm{C}$. Flow cytometric analysis was carried out in PBS ( $\left.\mathrm{pH} 4.0\right)$ to quench the extracellular fluorescence. Cellular uptake was determined as MFI. Data are presented as \% cellular uptake normalized to uptake of Zrfum/H6-GFP NPs at $37^{\circ} \mathrm{C} \pm$ SD $(n=3)$.

$80 \times 48 \mathrm{~mm}(300 \times 300 \mathrm{DPI})$ 

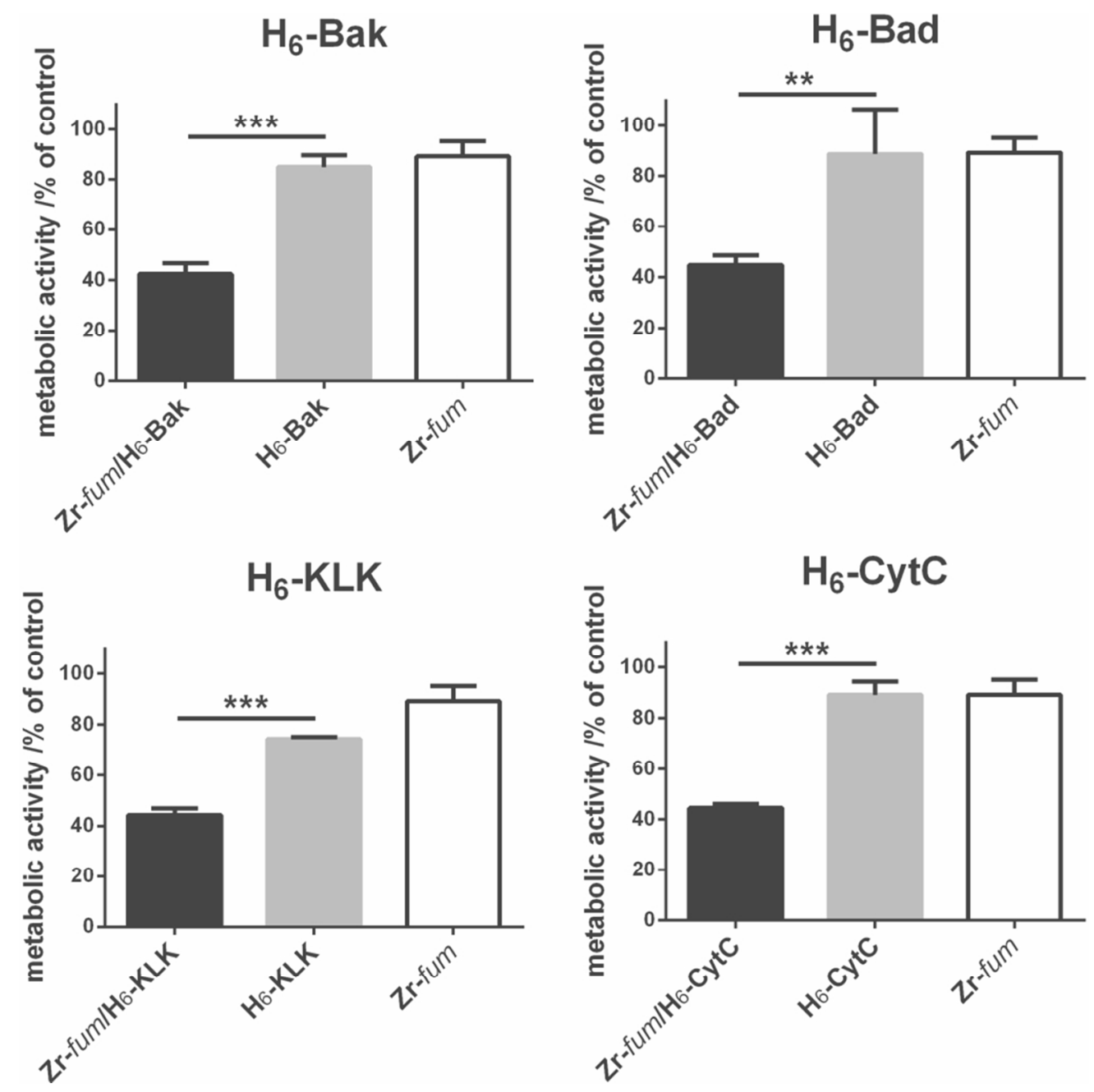

Figure 8. Intracellular transport of pro-apoptotic factors by Zr-fum MOF NPs and induction of HeLa cell killing upon incubation for $48 \mathrm{~h}$. Final concentration of H6-Bak, H6-Bad, H6-KLK, H6-CytC was $10 \mu \mathrm{M}(0.2 \mathrm{mg} \mathrm{Zr-}$ fum $/ 10 \mathrm{nmol}$ His-tag per $\mathrm{mL}$ medium). Data are presented as \% metabolic activity of control cells $\pm \mathrm{SD}$ $(n=3)$ (MTT assay). $86 \times 86 \mathrm{~mm}(300 \times 300$ DPI $)$ 


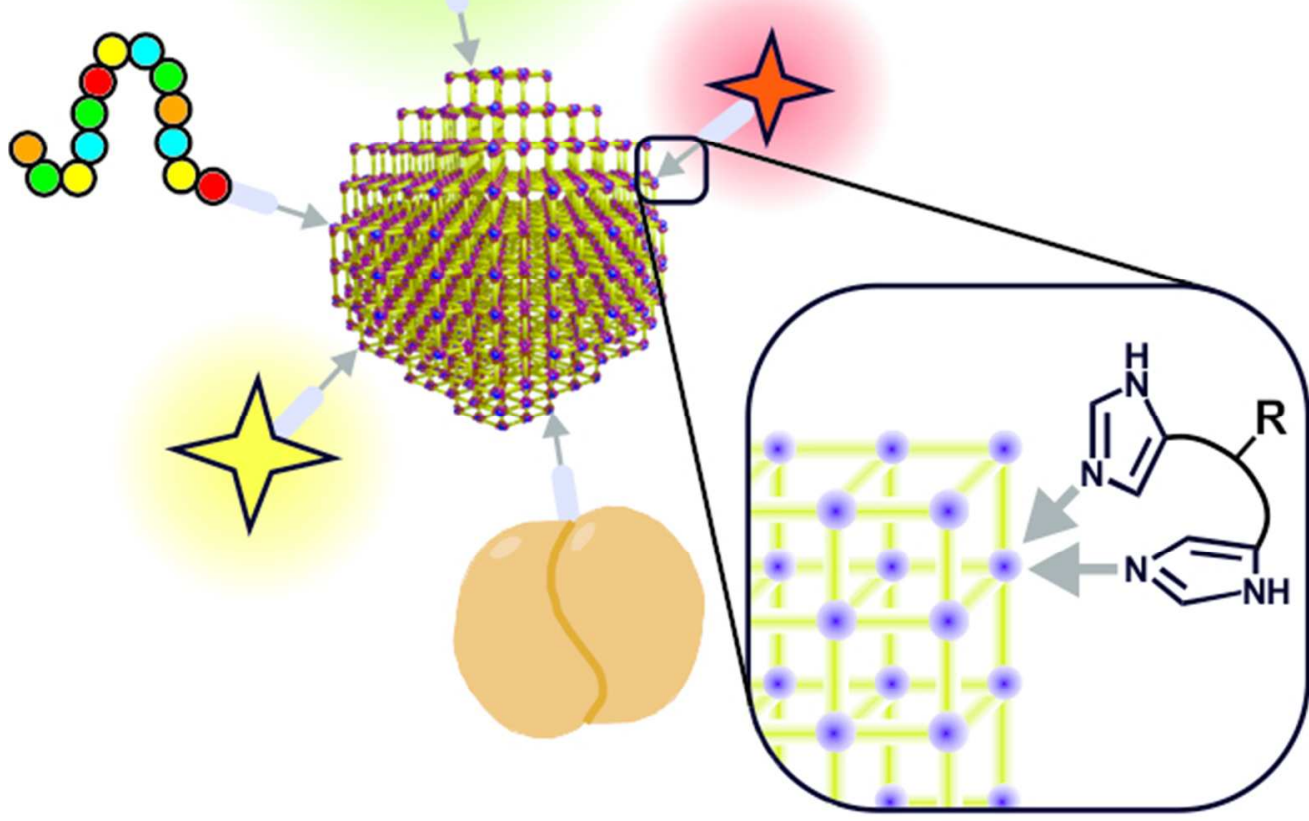

TOC Figure

$55 \times 51 \mathrm{~mm}(300 \times 300$ DPI $)$ 